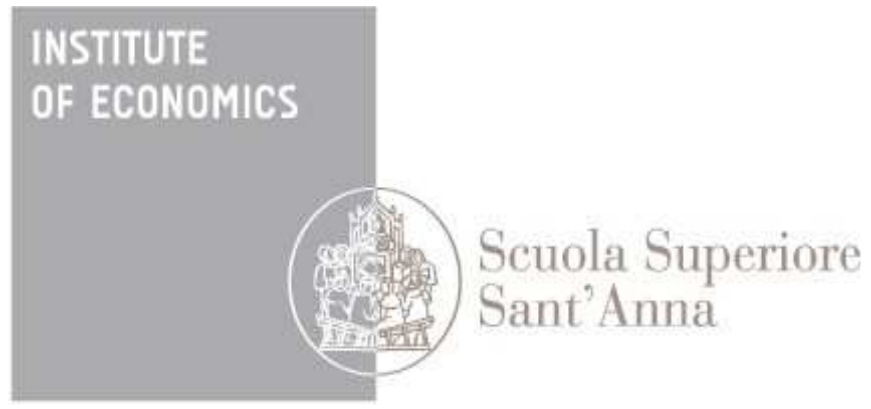

LEM | Laboratory of Economics and Management

Institute of Economics

Scuola Superiore Sant'Anna

Piazza Martiri della Libertà, 33 - 56127 Pisa, Italy ph. +3905088.33 .43$

institute.economics@sssup.it

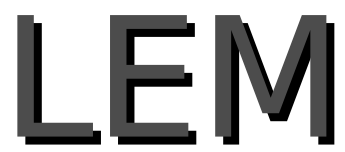

Working Paper Series

\title{
Innovation and within-firm wage inequalities: empirical evidence from major European countries
}

\author{
Valeria Cirillo ${ }^{\circ}$ \\ Matteo Sostero ${ }^{\circ}$ \\ Federico Tamagni ${ }^{\circ}$ \\ Institute of Economics, Scuola Superiore Sant'Anna, Pisa, Italy
}




\title{
Innovation and within-firm wage inequalities: empirical evidence from major European countries *
}

\author{
Valeria Cirillo $^{\mathrm{a}}$, Matteo Sostero ${ }^{\mathrm{a}}$, and Federico Tamagni ${ }^{\dagger a}$ \\ anstitute of Economics, Scuola Superiore Sant'Anna, Pisa, Italy
}

\begin{abstract}
A large literature analyses the links between wage inequality and technology, without explicitly taking into account within-firm wage dispersion. In this work we seek to fill this gap, exploiting a matched employeremployee dataset from a large representative survey on firms active in major European economies, providing several contributions. First, we employ different measures of within-firm wage dispersion, also accounting for wage differentials across managers vis-a-vis lower-layers occupations. Second, we disentangle the effects of innovation on wage dispersion within small vs. larger firms. Finally, we compare the effect of innovation across the spectrum between egalitarian and more unequal firms by means of quantile regressions. Our findings, robust to controlling for endogeneity and observed firm and workforce characteristics, suggest a good deal of heterogeneity. Indeed, innovation effects do vary according to the different measures of wage inequality, and also across smaller and larger innovative firms.
\end{abstract}

JEL codes: wage inequalities, innovation, quantile regressions, occupational wag-gap, employer-employee matched data

Keywords: J31, O30, C21

\footnotetext{
${ }^{*}$ This paper is produced within the project ISIGrowth for Innovation-fuelled, Sustainable, Inclusive Growth funded by the European Unions' Horizon 2020 research and innovation programme under grant agreement No.649186-ISIGrowth. The authors wish to thank Giovanni Dosi, Mario Pianta, Mauro Sylos Labini and the participants to the "Labour market and data" workshop held in Sapienza University of Rome, Faculty of Economics, on January 15, 2016. The usual disclaimers apply.

${ }^{\dagger}$ Corresponding author: Federico Tamagni, Scuola Superiore San'Anna, Pisa, Italy. Postal address: c/o Institute of Economics, Scuola Superiore Sant'Anna, Piazza Martiri 33, 56127, Pisa, Italy, E-mail f.tamagni@sssup.it, Tel +39-050883343.
} 


\section{Introduction}

Among the societal consequences of innovation, its potential impact on labour dynamics and wage inequality is one of the most traditionally investigated topics. This area of research constantly knows renewed attention, in relation to the steady appearance of new waves of fast technological change, related for instance to increasing diffusion of ICT, new forms of automation and robotization, and also in relation to the long-run consequences of the 2008 economic crisis. From a theoretical point of view, the literature has envisaged different channels through which innovation can affect wages and, consequently, wage dispersion. The Skill-biased and Routine-biased technical change hypotheses play a leading role, predicting that innovation creates inequalities by driving a wedge between the wages of workers differently exposed to innovation due to their skills or occupational status. The Rent-sharing theory emphasizes a different channel between wages and innovation, predicting that the rents deriving from innovative production activities are, at least partly, passed on to workers as higher wages. A vast empirical literature examines the "wage-premia" due to innovation, usually through wage equations estimated across groups of workers with different skills or different working positions within firms or considering their wage ratio.

In this work, we provide an empirical investigation of the relation between innovation and wage inequalities that arise within the firms. Within-firm wage dispersion is indeed important, as it accounts for almost the $60 \%$ of wage dispersion across all the individuals in the economy (Lazear and Shaw, 2007; Fournier and Koske, 2013). However, we do not know much about its relation with innovation. Indeed, the abovementioned theories linking innovation to wage dynamics do not predict direct effects of innovation on within-firm wage gaps, since such wage-gaps are essentially explained as an indirect result of the ability or likelihood of different types of workers to enjoy a wage premium due to innovation. This theoretical approach might have biased the empirical analysis towards overlooking the direct effects. Instead, in this work we pose the basic question whether within-firm wage inequalities are larger or lower in innovative vs. non-innovative firms.

We exploit a representative survey matching employer and employee data for four major European economies, and seek to provide a number of contributions to the literature. First, we want to examine the role of occupational status, as this can connect to the presence of different structure of power within the firms. Thus, we measure within-firm wage inequality not only as wage dispersion between highpaid vs. low-paid employees in the same firm, but also considering the wage-gap between managers and lower-layers workers. Second, we explicitly consider the mediating role of firm size. Size is known to be of crucial importance to the distribution of wages within firms, due to the more formalized organizational structure and wage-setting schemes that usually characterize larger firms. And size certainly has strong linkages also with the modes, sources and outcomes of innovation, since small and medium-large firms are well known to have different propensity to innovate, and to carry out their innovative activity in quite different ways, also according to the different technological regimes. But there is no evidence, to our knowledge, about the interplay of size and innovation in shaping withinfirm wage inequality. Third, we explicitly take into account firms' heterogeneity, and thus resort to quantile regressions that provide evidence on whether innovation has different effects on within-firm wage inequalities across firms characterized by different degrees of wage inequality, that is across more egalitarian vs. more unequal firms. 


\section{Background literature}

Wage inequalities have been connected to a variety of potential determinants, such as firm or plant-specific factors and performances (especially size and productivity,see Lazear, 1989; Milgrom and Roberts, 1990; Davis and Haltiwanger, 1995; Lallemand et al., 2004; Winter-Ebmer and Zweimüller, 1999), employment protection legislation and temporary contracts (Skans et al., 2006), type of collective bargaining (Dell'Aringa and Pagani, 2005), level of unionization (Freeman, 1982), labour mobility (Kandel and Lazear, 1992; Baker et al., 1994) and also to personal characteristics of workers, mostly focusing on skills (Zoghi, 2011; Zoghi and Mohr, 2012; Iranzo et al., 2008).

In this vast literature, a direct link between within-firm wage differentials and innovation has been less investigated. Existing studies provide a number of hints about the potential mechanisms linking the two, and about the potentially confounding factors, but a clear understanding of the relation is still lacking.

Theoretical mechanisms that link wage dynamics to innovation generally provide explanations for the wage inequalities observed across workers, or group of workers. There is not an explicit and specific focus on whether and how innovation directly impacts on inequalities within firms. Indeed, innovation plays an indirect role on the distribution of wages within firms, through its possible influence on the wage paid to workers that are more or less engaged in innovative activities. A first indirect mechanism is that described under the Skill-biased Technical Change approach (Acemoglu, 2002; Autor et al., 2003). This hypothesis has been widely investigated on data covering wages at the level of individuals, firms and sectors, confirming that there is indeed a wage premium for high-skilled over low-skilled workers. The more recent Routine-biased Technical Change explanation of wages and jobs polarization (Acemoglu and Autor, 2011) questions this conclusion, documenting the existence of wage differentials even among workers with comparable skills, thus stressing the importance for wage inequalities of the tasks and occupations of the different employees. To the extent that Skill-biased or Routine-biased mechanisms replicate within firms, polarizing the wages across co-workers with different skills or performing different tasks, than such mechanisms can also provide some explanation of the way innovation impacts on within-firm wage differentials.

Another theoretical mechanism that can be invoked to link innovation and within-firm wage dispersion is the Rent-sharing hypothesis. Also in this approach the link is indirect, but the potential sources of wage differences within the same firm go beyond the skills, the individual characteristics and the occupational status of workers. The core intuition in this framework is that innovation is a source of (Schumpeterian) rents, that can then be redistributed within the firm, in the form of either profits (retained by owners or further invested in the firm) or wages. Therefore, more innovative firms are expected to pay higher wages, at least to the extent that workers enjoy enough bargaining power to appropriate at least part of the innovation rents. However, the ensuing effects of this mechanism on within-firm wage inequality largely depend on whether the innovative rents appropriated by the employees are shared equally or unequally among the workers. The relative power of different occupational and professional categories within the firm is clearly likely to matter at this stage.

From this relatively limited literature on innovation and within-wage inequalities, we take a twofold lesson for our empirical analysis. First, while there is little guidance to predict whether innovative firms should display higher or lower wage inequalities than non-innovative firms, a number of workforce and institutional characteristics are likely to jointly influence both innovation propensity of firms and their 
pay structures, requiring appropriate treatment for such potentially confounding factors. Second, occupational and professional status within the firm may play a relevant role in the generation of innovation-related wage differences within firms. In other words, one should consider the effects of innovation not only on "neutral" measures of wage inequality that return a merely statistical description of the wage distribution within the firm, but also on measures that capture the occupational content of wage inequalities, accounting for the differential ability of apical vs. lower-layers occupations to appropriate the returns from innovation.

In addition, we also refer to a large literature that connects within- firm wage dispersion to a number of firm-level characteristics, beyond innovation propensity. Most of these characteristics somehow transfer at the firm level the focus on workers' characteristics traditionally studied to explain differences in individual worker wages. Thus, wage dispersion within firms has been linked to personal characteristics of the workforce composition, such as average age, skills, tenure, education levels, relative presence of male and females, incidence of different job contracts and levels and type of wage bargaining. Beyond these features, firm size has received a special attention, and it has been repeatedly recognized in the empirical literature as a leading determinant of within-firm wage dispersion, usually finding that larger firms display a more unequal wage distribution (Davis and Haltiwanger, 1991, 1995; Mueller et al., 2015). Theoretically, there are several reasons why size could not only be important per se, but also in connection with innovation. On a more general level, innovation scholars have repeatedly documented that the innovation- size interactions are crucial for the very generation of innovation, according to classical Schumpeterian distinction between creative destruction and creative accumulation, predicting that either smaller or larger firms may be the drivers of innovation in different industries and technologies. On the other hand, and more specifically, the observed leading role of firm size on within-firm wage dispersion is usually explained in the literature by a combination of factors related to labour market institutions, firms' organizational traits and - exactly - technology. Indeed, as emphasized by Brown and Medoff (1989), the often documented positive relation between size and within-firm (or within-plant) wage dispersion can have two explanations. On the one hand, larger firms usually display a more diversified internal organization and workforce, also in relation to technology and innovative propensity, because they need to carry out more diversified tasks. On the other hand, larger firms make more frequent use of incentive-based mechanisms, thus leading to wider pay differentials. Of course, along the same lines, a negative relation between firm size and withinplant dispersion shall be explained in terms of technologies requiring more homogeneous workers, or by unions' effort to compress wage differentials among workers, which is more likely to happen in larger firms (Nickell and Wadhwani, 1990; Nickell et al., 1994). We also stress the role of size in our analysis, to account for the interplay of innovation and size in affecting wage inequalities within firms.

\section{Research questions and empirical framework}

We investigate two features of the relation between innovation and within-firm wage dispersion. First, we pose the basic question whether innovative and non-innovative firms display differences in wage dispersion. We address this question through the following regression model:

$$
w_{j}^{d}=\alpha+\beta \operatorname{Innov}_{j}+\gamma \mathbf{Z}_{j}+\epsilon_{j} .
$$


The dependent variable $w^{d}$ is, alternatively, either of two suitably complementary measures of withinfirm wage dispersion that we compute for each firm $j$, in order to capture different facets of the phenomenon, in terms of both the inequalities across low-paid vs. high-paid employees and also between top-layer vs. bottom-layer occupations. The key regressor Innov is a dummy indicator that identifies innovative firms, while $\mathbf{Z}$ is a set of control variables, among others also containing a dummy distinguishing small from medium-large firms. The coefficient of primary interest is $\beta$, capturing whether innovators have higher or lower wage dispersion than non-innovators.

The second research question addresses the combined role of firm size and innovation in shaping wage dispersion within firms. The separate role of size on wage dispersion has been relatively largely investigated. We here want to uncover if firm size has also a relevant mediating role in the relation between innovation and within-firm wage dispersion. We formalize this intuition through a regression model with innovation-size interaction. We extend Eq. (1), as follows

$$
w_{j}^{d}=\alpha+\beta \operatorname{Innov}_{j}+\delta \operatorname{Innov}_{j} \times \operatorname{Size}_{j}+\gamma \mathbf{Z}_{j}+\epsilon_{j} .
$$

In this regression, Size is a dummy equal to 1 for medium-large firms. Since, as mentioned above, the firm size dummy is also included without interaction in the set of controls $\mathbf{Z}$, then the coefficient $\beta$ on the Innov dummy gives the difference in wage dispersion observed for small innovative firms as compared to the control group of small non-innovative firms, while the interaction coefficient $\delta$ accounts for the differences in wage dispersion across small vs. medium-large innovators.

In estimating regression models (1) and (2), we complement standard OLS estimates with quantile regressions. OLS accounts for the association of innovation, size and other factors with the conditional average of within-firm wage dispersion. Quantile regressions provide a richer picture, allowing to explore the variation of the coefficients over the quantiles of the distribution of wage dispersion. That is, we can address whether innovation, size and other factors have different association with withinfirm wage dispersion across "more egalitarian" firms, in the bottom quantiles of the wage dispersion distribution, vs. "more unequal" firms in the top quantiles. In particular, we use simultaneous quantile regressions, which allow to more directly compare the coefficient estimates across quantiles.

Since we do not benefit from a panel dataset enabling for usual treatment of unobserved firm heterogeneity, we include a relatively large number of controls in the set $\mathbf{Z}$. These include firm-level characteristics directly available in the data, as well as a set of personal and workforce characteristics derived from employee-level information, and an innovation index that accounts for sectoral and regional patterns of innovation (see the next Section 4 for details). While all these factors should considerably reduce omitted variable bias, in Section 6 we design a procedure to control for potential endogeneity arising from joint determination of Innov and wage dispersion. Finally notice that all the regressions include sector and country fixed effects, so that identification of the main "innovation effects" comes from variation within sectors and countries, across innovative and non-innovative firms.

\section{Data, main variables, and descriptive evidence}

In this section we present the data, define our measures of wage dispersion and innovation, and provide descriptive evidence about the structure of the innovation-wage dispersion relation. 


\subsection{Sources and sample}

The empirical analysis relies upon the European Union Structure of Earnings Survey (SES) maintained by EUROSTAT, a matched employer-employee dataset that has been repeatedly used to study labour dynamics across European countries. Indeed, SES data represent a uniquely source of information for a consistent comparison of earnings and work-related variables across European economies.

For this work we have access to the 2010 version of SES for four major European economies, namely Germany, Spain, France and Italy. For each country the data cover a representative sample of firms (stratified by size, sector and geographical area) active in different sectors of activity. For each firm, the data then report individual-level information about a representative sample of employees working within the firm. For each sampled employee, we observe personal characteristics (age class, gender, education level, tenure, professional occupation), as well as wages. The data also cover a limited set of firm characteristics: the firm size class (in terms of number of employees), public vs. private ownership, use of collective bargaining agreements, and the sector of primary activity according to European NACE taxonomy.

Of course, the dataset has its own limitations. First, the survey is restricted to business units with at least 10 employees. Second, the rates of employees sampled within each firm varies by country (see Figure 1 in the Appendix) thus limiting the information available in some countries.

The main outcome under scrutiny is within-firm wage dispersion, which can be computed from wages of the employees sampled in SES within each firm. This necessarily involves a number of choices concerning type of employees considered, type of contracts, and the time unit to take as reference for wages. We restricted the sample to include only full-time employees with at least eight working weeks in the reference year, and take the annual wage as the measure of individual wage for our analysis. Moreover, in order to have a meaningful number of employees to compute dispersion within each firm, we further restrict the sample to firms with at least three sampled employees. ${ }^{1}$

\subsection{Main variables}

In computing our measures of within-firm wage dispersion, we follow the standard practice in the literature on within-firm wage inequality (at least since Winter-Ebmer and Zweimüller, 1999), to use adjusted individual wages, and not the raw wages reported in the data. Adjusted wages, $\hat{w}$, are computed as the residual of a preliminary Mincer-type individual wage regression

$$
\log \left(w_{i}\right)=\beta_{0}+\beta_{1} \text { age }_{i}+\beta_{2} \operatorname{exper}_{i}+\beta_{3} \operatorname{exper}_{i}^{2}+\beta_{4} \text { male }_{i}+\beta_{5} \text { educ }_{i}+\beta_{6} \operatorname{temp}_{i}+\beta_{7} \text { occup }_{i}+\beta_{8} \mathrm{FE}_{j}+\hat{w}_{i}
$$

where the raw wage $w_{i}$ of employee $i$ is regressed (in logs) against firm-fixed effects $F E_{j}$ and a set of personal characteristics: age, tenure in the firm (exper), a dummy for male workers (male), a dummy for tertiary education (educ), information on professional occupation (occup) from ISCO categories, and a dummy for whether the employee has a temporary contract (temp).

Then, based on the residuals, we employ two complementary definitions of within-firm wage dispersion. We first look at the distance between the $90^{\text {th }}$ and the $10^{\text {th }}$ percentile of the distribution of

\footnotetext{
${ }^{1}$ Figure 2 in the Appendix shows that restricting to firms with a higher number of employees sampled does not seem to affect the distribution of wage dispersion across firms.
} 
individual wages observed within firm $j$

$$
w_{j}^{d 1}=\left(\frac{\hat{w}_{j}^{0.90}}{\hat{w}_{j}^{0.10}}\right)
$$

yielding a statistical representation of the distance between high-paid vs. low-paid employees.

Second, we want a measure that similarly looks at top vs. bottom wages, but that can also suitably account for wage differences related to professional and occupational status between senior positions vs. low-layers employees. We employ the information on the professional occupation of each employee (available in SES according to the 2008 International Standard Classification of Occupations, ISCO), and then distinguish "Managers" (ISCO code 1) and "Low-layers" employees (ISCO codes 7,8 and 9, respectively including "craft and related trades workers", "plant and machine operators and assemblers", and "elementary occupations"). We thus define our second measure of wage dispersion as the wage-gap between these two categories:

$$
w_{j}^{d 2}=\left(\frac{\mathbb{E}_{j}\left(\hat{w}^{\text {managers }}\right)}{\mathbb{E}_{j}\left(\hat{w}^{\text {lower-level }}\right)}\right)
$$

taking, for each firm $j$, the average $(\mathbb{E})$ wage computed within each category if more than one employee is present in the firm for that category. This definition requires observing at least one manager and one lower-level employee in any given firm, and it is thus more restrictive in terms of sample size than $w_{j}^{d 1}$.

The adjustment via the preliminary Mincerian regression has two implications for the estimation of the regression models in Eq. 1 and Eq. 2. First, since the residuals $\hat{w}_{i}$ are log-adjusted wages, then the dependent variables $w_{j}^{d 1}$ and $w_{j}^{d 2}$ are implicitly defined as log-ratios. More importantly, the adjustment cleans the two measures of wage dispersion for systematic relationship between wages and employee or firm characteristics that would otherwise influence the relation between wage dispersion and innovation in estimating the regression models.

Concerning the proxy for firm-level innovation, we are somewhat constrained by the limited amount of firm characteristics directly available in SES. Moreover, as it is common, the data are stripped of all identifiable information, including firm names, a fact that prevents from matching the SES dataset with other firm-level data sources. We can however exploit the possibility to identify the number of researcher employed by a firm, through individual information on the ISCO professional occupations of the employees. Accordingly, our key regressor capturing firm innovativeness is a dummy variable Innov that defines a firm as innovative $($ Innov $=1)$ if we observe at least one employee who is engaged in research activity within the firm as defined by ISCO codes 21 or 22 ("Science and engineering or health professionals"). Because of the random sampling of employees, firms covered in SES are expected to give a fair representation of their workforce. We can therefore expect each firm employing researchers to sample at least one of them. If there is a bias in sampling, we may fail to classify as innovative a firm that has researchers in the workforce, but does not sample any of them. We can therefore expect the Innov dummy to provide a conservative estimate of the differences between innovative and non-innovative firms.

We also exploit the available information from SES data to define the variables included in the set of controls Z. First, we include a set of firm-level characteristics directly measured in SES. As 
mentioned, we capture firm size as a dummy distinguishing medium-large firms with 50 or more employees from smaller firms, and we also include two dummies respectively indicating whether the firm is under public control and whether the firm does not apply any form of collective agreement in wage-setting. Previous studies tend to suggest that larger firms display higher wage dispersion, also in connection with the typically more common presence of unionization in larger firms, as indeed forms of collective bargaining have been found to reduce wage-gaps within firm, according to an overall "egalitarian" goal pursued by unions. Whether public control displays any effect on wage dispersion within firms has been less investigated. There is a sort of public pressure in some countries to limit the compensation of highly-paid occupations within public firms, that can result into reduced within-firm inequality in public vs. private firms. But, of course, relatively high wages and wage-gaps may also be possible in public firms. Secondly, we include a set of personal characteristics of the workforce of each firm, computed from the individual information on the employees sampled within each firm. We include the modal age of the employees (as dummies for cohort effects), the share of employees with tertiary education, the share of males, and the average tenure. All these factors are expected to be positively associated with average wages in the firm, since it is indeed usually the case that older, more educated, longer-serving, and male employees have higher wages. However, their association with wage differentials within the firm is uncertain a-priori, depending from "compositional effects" due to how these personal characteristics differ across the groups of employees that we compare in the different measures of wage dispersion. For instance, in terms of the $90^{\text {th }}$-to- $10^{\text {th }}$ wage ratio, a firm with a $100 \%$ share of males can even be less unequal than a firm with at least one woman, to the extent that men earn relatively similar wages in the former firm. A similar reasoning applies to other personal characteristics of the workforce. Third, and again starting from employee-level information, we also measure two "structural" (non-personal) features of the workforce composition in the firm. These are the share of apical occupations ("Managers and Professionals", as from ISCO codes 1 and 2) and the share of employees with a temporary job contract. One expects the former to increase average wages within firms, since managers and professionals are typically paid higher wages than other employees, while the opposite is likely to hold for the share of temporary contracts, since such jobs are usually less paid than permanent jobs. As mentioned above with regards to personal characteristics, however, compositional effects again prevent a clearcut prediction about the relationship between these controls and within-firm wage inequalities.

Finally, among the controls we also include an innovation index that combines features of innovation dynamics occurring at the level of sector and geographical areas where each firm is active. The index is built following the literature on multidimensional indicators (see for instance Betti et al., 2006; Martinetti, 1994, for applications to poverty and well- being). Information on regional patterns of innovation is taken from EUROSTAT data. We consider three variables: the share of scientists and engineers and the share of persons employed in science and technology from EU Labour force survey (LFS), and the number of patent applications to the EPO per million of inhabitants from PATSTAT database, each measured at the level of NUTS 1-digit regions, since this is the information we have on the geographical location of firms in SES. On the other hand, information on sectoral patterns of innovation is taken from the Community Innovation Survey (CIS). We take 2-digit level of sectoral disaggregation and consider the following indicators: the share of firms declaring to introduce product innovations, the intensity of $R \& D$ (as expenditures per employee), and the share of turnover due to 
Table 1: Summary statistics, by innovation status and country

\begin{tabular}{|c|c|c|c|c|c|c|c|c|}
\hline \multirow{2}{*}{$\begin{array}{l}\text { Country } \\
\text { Innovation dummy }\end{array}$} & \multicolumn{2}{|c|}{ DE } & \multicolumn{2}{|c|}{ ES } & \multicolumn{2}{|c|}{ FR } & \multicolumn{2}{|c|}{ IT } \\
\hline & 0 & 1 & 0 & 1 & 0 & 1 & 0 & 1 \\
\hline \\
\hline Mean $w^{d 1}$ & 0.4912 & 0.5065 & 0.3604 & 0.4633 & 0.4025 & 0.4857 & 0.4719 & 0.5827 \\
\hline N. firms & 8247 & 3124 & 4543 & 1505 & 3327 & 1308 & 4930 & 362 \\
\hline Share of large firms & 0.3536 & 0.7414 & 0.3447 & 0.6545 & 0.5293 & 0.8647 & 0.4296 & 0.7431 \\
\hline Median n. employees sampled & 21 & 65 & 5 & 10 & 5 & 13.5 & 11 & 24 \\
\hline \multicolumn{9}{|l|}{ Firms for which $w^{d 2}$ is defined } \\
\hline Mean $w^{d 2}$ & 0.1198 & -0.0134 & -0.0401 & 0.0245 & 0.0587 & -0.0593 & 0.0147 & 0.0143 \\
\hline N. firms & 2770 & 1948 & 612 & 279 & 1010 & 619 & 391 & 81 \\
\hline Share of large firms & 0.5101 & 0.8368 & 0.6650 & 0.9140 & 0.6792 & 0.9596 & 0.7315 & 0.8889 \\
\hline Median n. employees sampled & 37 & 73 & 10 & 19 & 6 & 21 & 23 & 32 \\
\hline
\end{tabular}

process innovation. After normalizing the regional and sectoral variables from their respective unit of measurement into the $[0,1]$ interval, we aggregate them into an index that varies by sector $s$ and region $r$, as follows

$$
\text { innov_index }_{s, r}=\frac{1}{2} \sum_{k \in\left\{s_{1}, s_{2}, s_{3}\right\}} w_{k, s} m_{k, s}+\frac{1}{2} \sum_{k \in\left\{r_{1}, r_{2}, r_{3}\right\}} w_{k, r} m_{k, r}, \quad w_{k}=\frac{\mathbb{E}\left(m_{k}\right)}{\sum_{k} \mathbb{E}\left(m_{k}\right)}
$$

where $\left\{s_{1}, s_{2}, s_{3}\right\}$ and $\left\{r_{1}, r_{2}, r_{3}\right\}$ are, respectively, the three sector and regional-level variables mentioned above, and $m_{k}=F_{k}\left(x_{k}\right)$ is the normalizing function, with $F_{k}\left(x_{k}\right)$ the empirical cumulative distribution function of each variable $x_{k}$. The index cleans our dummy for innovative firms Innov from otherwise unmeasured factors operating at the sectoral and regional level that can influence the firm propensity to hire researchers and, thus, the innovation status of firms.

\subsection{Descriptive evidence}

Table 1 shows basic summary statistics for the (adjusted) measures of wage dispersion $w^{d 1}$ and $w^{d 2}$, the share of medium-large firms, and the number of sampled employees, across innovative vs. noninnovative firms and by country.

Innovative firms tend to display a larger share of medium-large firms than non-innovative firms, as opposed to a lower (average and median) number of sampled employees. The average of the quantilesbased dispersion measure $w^{d 1}$ is higher for innovative firms than for non-innovators in all countries considered, although the differences across innovation status are modest in Germany, while stark in the other countries. The evidence for the wage dispersion among professions $w^{d 2}$ tends to go the other way: the average is lower for innovators than for non-innovators in Germany, France, and Italy, while it is higher for Spain only. Since the definition of $w^{d 2}$ requires to observe at least both a manager and a lower-layer employee in the firm, the sample of firms for which we can observe this measure of dispersion includes fewer and larger firms, with more employees sampled, as compared to the sample for which $w^{d 1}$ can be defined.

In Table 2 we provide a basic mean-difference test across innovative and non-innovative firms via a basic OLS regression of both the (adjusted) dispersion measures against the Innov dummy, without 
Table 2: Innovation and within-firm wage dispersion, OLS mean-difference test

\begin{tabular}{lcc}
\hline Dep.Var. & $w^{d 1}$ & $w^{d 2}$ \\
\hline Innov & $0.0518^{* * *}$ & $-0.0965^{* * *}$ \\
& $(0.00297)$ & $(0.00975)$ \\
Constant & $0.444^{* * *}$ & $0.0778^{* * *}$ \\
& $(0.00160)$ & $(0.00656)$ \\
\hline
\end{tabular}

Standard errors in parentheses, clustered at the firm level.

Significance levels: ${ }^{*} p<0.05,{ }^{* *} p<0.01,{ }^{* * *} p<0.001$

controls. We observe higher inequality across innovators for the $90^{\text {th }}$-to- $10^{\text {th }}$ percentile wage-gap $w^{d 1}$, while the professional wage-gap $w^{d 2}$ accounting for occupational status is larger across non-innovative firms. This contrasting result, preliminary as it is, confirms that innovation can have non-trivial relations with the different measures of wage inequality that we use here. As such, it supports the importance to consider different facets of within-firm wage inequalities.

\section{$5 \quad$ Main results}

We here present our baseline estimates of the regression models developed in Section 3. We start by exploring the direct association between innovation and wage dispersion, and then present the analysis considering the potential mediating role of firm size.

\subsection{Innovation and wage dispersion}

Table 3 shows the estimates of the specification in Eq. (1), taking the (adjusted) $90^{\text {th }}$-to- $10^{\text {th }}$ percentile wage ratio $w^{d 1}$ as the dependent variable. ${ }^{2}$ The main finding is that wage inequality varies with innovation across the quantiles of the within-firm wage dispersion distribution. Indeed, the estimates of the coefficient on the Innov dummy reveal a positive and significant relation from the bottom quantiles to the median, but the strength of association is decreasing in magnitude and it indeed turns to not significant at the $75^{\text {th }}$ quantile, and eventually negative in the top quantiles. Thus, innovative firms display higher wage dispersion than non-innovative firms if we take more egalitarian firms in the left and central part of the support, while among relatively extreme unequal firms innovators show a lower wage dispersion.

Among the firm-level controls, the estimates on the dummy for firm size imply that medium-large firms display a significantly higher wage dispersion than small firms, and this "size effect" is significant along all the quantiles of the wage dispersion distribution. This is in line with previous results in the literature suggesting that wage dispersion increases with firm size. Similarly, the absence of any form of collective bargaining is associated to a larger wage-gap in all the quantiles of the wage dispersion distribution, and in particular among more unequal firms in the top quantiles. The result speaks to the large literature on the role of unionization and decentralization of wage bargaining, confirming previous findings that the absence of any form of collective wage setting can contribute to exacerbate wage inequalities. Conversely, we find that wage dispersion is lower in firms under public control than

\footnotetext{
${ }^{2}$ For the OLS we report robust standard errors clustered at firm level, while bootstrapped standard errors (over 100 bootstrap runs) are reported in the case of quantile regressions. The same applies throughout the whole paper.
} 
Table 3: Innovation and within-firm wage dispersion as the $90^{\text {th }}$-to- $10^{\text {th }}$ percentile wage ratio.

\begin{tabular}{|c|c|c|c|c|c|c|}
\hline & \multirow[b]{2}{*}{ OLS } & \multicolumn{5}{|c|}{ Simultaneous Quantile Regression } \\
\hline & & q10 & $\mathrm{q} 25$ & q50 & q75 & q90 \\
\hline Innov & $\begin{array}{c}0.0110^{* *} \\
(0.00361)\end{array}$ & $\begin{array}{l}0.0351^{* * *} \\
(0.00383)\end{array}$ & $\begin{array}{l}0.0226^{* * *} \\
(0.00201)\end{array}$ & $\begin{array}{l}0.0129 * * * \\
(0.00257)\end{array}$ & $\begin{array}{c}-0.00309 \\
(0.00497)\end{array}$ & $\begin{array}{c}-0.0272^{* * *} \\
(0.00769)\end{array}$ \\
\hline Medium-large firm & $\begin{array}{l}0.0735^{* * *} \\
(0.00280)\end{array}$ & $\begin{array}{l}0.0899 * * * \\
(0.00203)\end{array}$ & $\begin{array}{l}0.0861^{* * *} \\
(0.00173)\end{array}$ & $\begin{array}{l}0.0771^{* * *} \\
(0.00257)\end{array}$ & $\begin{array}{l}0.0699 * * * \\
(0.00282)\end{array}$ & $\begin{array}{l}0.0459^{* * *} \\
(0.00659)\end{array}$ \\
\hline Innov index & $\begin{array}{c}0.153^{* * *} \\
(0.0192)\end{array}$ & $\begin{array}{c}0.0539 * * \\
(0.0204)\end{array}$ & $\begin{array}{l}0.0657^{* * *} \\
(0.0192)\end{array}$ & $\begin{array}{l}0.124^{* * *} \\
(0.0212)\end{array}$ & $\begin{array}{c}0.197^{* * *} \\
(0.0262)\end{array}$ & $\begin{array}{c}0.213^{* * *} \\
(0.0347)\end{array}$ \\
\hline Public firms & $\begin{array}{c}-0.0315^{* * *} \\
(0.00645)\end{array}$ & $\begin{array}{c}-0.00375 \\
(0.00757)\end{array}$ & $\begin{array}{c}-0.00815 \\
(0.00586)\end{array}$ & $\begin{array}{c}-0.0286^{* * *} \\
(0.00555)\end{array}$ & $\begin{array}{c}-0.0429^{* * *} \\
(0.00538)\end{array}$ & $\begin{array}{c}-0.0588^{* * *} \\
(0.00803)\end{array}$ \\
\hline No coll. agr. & $\begin{array}{l}0.0758^{* * *} \\
(0.00367)\end{array}$ & $\begin{array}{l}0.0259^{* * *} \\
(0.00436)\end{array}$ & $\begin{array}{l}0.0471^{* * *} \\
(0.00388)\end{array}$ & $\begin{array}{l}0.0729^{* * *} \\
(0.00383)\end{array}$ & $\begin{array}{c}0.101^{* * *} \\
(0.00586)\end{array}$ & $\begin{array}{l}0.122^{* * *} \\
(0.0102)\end{array}$ \\
\hline Modal age empl. & & & & & & \\
\hline $14-19$ & $\begin{array}{c}-0.00892 \\
(0.0193)\end{array}$ & $\begin{array}{r}0.00570 \\
(0.0162)\end{array}$ & $\begin{array}{c}-0.0139 \\
(0.0212)\end{array}$ & $\begin{array}{c}-0.0105 \\
(0.0226)\end{array}$ & $\begin{array}{c}-0.0163 \\
(0.0178)\end{array}$ & $\begin{array}{c}-0.0275 \\
(0.0346)\end{array}$ \\
\hline $20-29$ & $\begin{array}{c}-0.00390 \\
(0.00445)\end{array}$ & $\begin{array}{c}-0.00312 \\
(0.00509)\end{array}$ & $\begin{array}{c}-0.00558 \\
(0.00411)\end{array}$ & $\begin{array}{c}-0.00830 \\
(0.00546)\end{array}$ & $\begin{array}{r}-0.00513 \\
(0.00575)\end{array}$ & $\begin{array}{c}-0.000751 \\
(0.0108)\end{array}$ \\
\hline $40-49$ & $\begin{array}{c}-0.0149 * * * \\
(0.00340)\end{array}$ & $\begin{array}{c}-0.00908^{* *} \\
(0.00352)\end{array}$ & $\begin{array}{c}-0.0117^{* * *} \\
(0.00265)\end{array}$ & $\begin{array}{c}-0.0169 * * * \\
(0.00311)\end{array}$ & $\begin{array}{c}-0.0117^{*} \\
(0.00462)\end{array}$ & $\begin{array}{c}-0.0166^{*} \\
(0.00784)\end{array}$ \\
\hline $50-59$ & $\begin{array}{c}-0.0108^{*} \\
(0.00435)\end{array}$ & $\begin{array}{c}-0.0160^{* * *} \\
(0.00303)\end{array}$ & $\begin{array}{c}-0.0120^{* * *} \\
(0.00272)\end{array}$ & $\begin{array}{c}-0.0115^{*} \\
(0.00469)\end{array}$ & $\begin{array}{c}-0.00375 \\
(0.00621)\end{array}$ & $\begin{array}{c}0.00361 \\
(0.0102)\end{array}$ \\
\hline $60+$ & $\begin{array}{c}0.0436 \\
(0.0291)\end{array}$ & $\begin{array}{c}0.00522 \\
(0.0120)\end{array}$ & $\begin{array}{c}-0.0153 \\
(0.0282)\end{array}$ & $\begin{array}{c}0.0584^{*} \\
(0.0281)\end{array}$ & $\begin{array}{c}0.0741 \\
(0.0526)\end{array}$ & $\begin{array}{l}0.196^{* * *} \\
(0.0486)\end{array}$ \\
\hline$\%$ empl. tertiary ed. & $\begin{array}{c}0.000700^{* * *} \\
(0.0000953)\end{array}$ & $\begin{array}{l}0.000420^{* * *} \\
(0.000103)\end{array}$ & $\begin{array}{c}0.000352^{* * *} \\
(0.0000683)\end{array}$ & $\begin{array}{l}0.000607^{* * *} \\
(0.000103)\end{array}$ & $\begin{array}{l}0.000753^{* * *} \\
(0.000121)\end{array}$ & $\begin{array}{c}0.00125^{* * *} \\
(0.000194)\end{array}$ \\
\hline Average tenure empl. & $\begin{array}{c}-0.00279^{* * *} \\
(0.000263)\end{array}$ & $\begin{array}{c}-0.00122^{* * *} \\
(0.000265)\end{array}$ & $\begin{array}{c}-0.00167^{* * *} \\
(0.000262)\end{array}$ & $\begin{array}{c}-0.00232^{* * *} \\
(0.000227)\end{array}$ & $\begin{array}{c}-0.00408^{* * *} \\
(0.000397)\end{array}$ & $\begin{array}{c}-0.00469^{* * *} \\
(0.000403)\end{array}$ \\
\hline$\%$ ISCO $1-2$ & $\begin{array}{c}0.00144^{* * *} \\
(0.0000986)\end{array}$ & $\begin{array}{c}0.000726^{* * *} \\
(0.0000983)\end{array}$ & $\begin{array}{c}0.00121^{* * *} \\
(0.0000686)\end{array}$ & $\begin{array}{c}0.00161^{* * *} \\
(0.0000879)\end{array}$ & $\begin{array}{c}0.00206^{* * *} \\
(0.0000773)\end{array}$ & $\begin{array}{c}0.00230^{* * *} \\
(0.000265)\end{array}$ \\
\hline$\%$ Perm. contracts & $\begin{array}{l}-0.000102 \\
(0.0000927)\end{array}$ & $\begin{array}{c}-0.0000952 \\
(0.0000698)\end{array}$ & $\begin{array}{c}-0.0000648 \\
(0.000101)\end{array}$ & $\begin{array}{r}-0.0000678 \\
(0.000120)\end{array}$ & $\begin{array}{c}0.0000746 \\
(0.0000858)\end{array}$ & $\begin{array}{r}-0.0000427 \\
(0.000209)\end{array}$ \\
\hline$\%$ Males & $\begin{array}{c}-0.000393^{* * *} \\
(0.0000600)\end{array}$ & $\begin{array}{c}-0.000197^{* * *} \\
(0.0000449)\end{array}$ & $\begin{array}{c}-0.000325^{* * *} \\
(0.0000599)\end{array}$ & $\begin{array}{c}-0.000392^{* * *} \\
(0.0000578)\end{array}$ & $\begin{array}{c}-0.000535^{* * *} \\
(0.000101)\end{array}$ & $\begin{array}{c}-0.000893^{* * *} \\
(0.000143)\end{array}$ \\
\hline Constant & $\begin{array}{c}0.410^{* * * *} \\
(0.0160) \\
\end{array}$ & $\begin{array}{c}0.157^{* * * *} \\
(0.0170) \\
\end{array}$ & $\begin{array}{l}0.254^{* * *} \\
(0.0193)\end{array}$ & $\begin{array}{c}0.366^{* * *} \\
(0.0186)\end{array}$ & $\begin{array}{l}0.501^{* * *} \\
(0.0211)\end{array}$ & $\begin{array}{l}0.737^{* * *} \\
(0.0389)\end{array}$ \\
\hline Observations & 27346 & 27346 & & & & \\
\hline Sector fixed effects & Yes & Yes & & & & \\
\hline Country fixed effects & Yes & Yes & & & & \\
\hline
\end{tabular}

Estimates of Eq. (1), with $w^{d 1}$ as the dependent variable.

Standard errors in parentheses, clustered at the firm level. Significance levels: ${ }^{*} p<0.05,{ }^{* *} p<0.01,{ }^{* * *} p<0.001$ 
in privately owned firms, but this "equality-enhancing" effect is significant only in the central and right part of the wage dispersion distribution (for $\mathrm{q}_{50}, \mathrm{q}_{75}$ and $\mathrm{q}_{90}$ ). This is consistent with previous findings in the literature suggesting that the distance between top and lower paid employees is much wider in private firms, also due to the provision of formal caps to the remuneration of top-layers positions in companies under public control.

Next, personal characteristics and composition of the workforce influence wage dispersion as well. Age shows non-trivial interactions. On the one hand, we do not find any significant relationship with wage dispersion for firms with a relatively younger workforce than the baseline category of firms with modal age of 30-39 years. On the other hand, we find a lower wage dispersion in firms with older workforce (40-49 and 50-59 years modal age). Further, the average tenure and the share of males in the workforce are both inversely related with inequality, along all the quantiles of the distribution of wage dispersion. Since longer-tenured and male workers are known to usually enjoy higher wages than shorter-tenured and females employees, the estimates capture the result of compositional effects whereby, no matter if we take more or less egalitarian firms in different quantiles, a more homogeneous workforce composition in terms of tenure duration and gender gets reflected into a lower distance between high-paid and low-paid employees within the firm. On the contrary, wage dispersion increases with the share of high-educated workers (with tertiary education) and with the share of more professionalized employees (with occupations as managers and professionals, ISCO categories 1 and 2), along the entire wage dispersion distribution. Although also these categories usually enjoy higher wages, compositional effects seem to work in an opposite direction as compared to what observed for tenured and male employees. A higher proportion of educated and professionals employees in the workforce does not get reflected into a more homogeneous workforce and wage structure. The last control on workforce composition, i.e. the share of workers having a permanent contract, does not display any statistically significant association with wage dispersion. This can be surprising, since permanent contracts are usually associated with higher wages, and one can thus expect that compositional effects can get reflected into reduced wage inequalities in firms where more people enjoy a permanent contract. An explanation for the observed absence of correlation may be that there is not enough variation, with indeed most workers having this type of contracts in all firms. But we verified that this is not the case in the data, and therefore a more convincing explanation seems to be that part of the "contract type effect" is already absorbed by the collective bargaining dummy discussed above.

Lastly, we find positive and significant coefficient estimates on the index capturing sectoral and regional patterns of innovation, in all the quantiles. This finding, per se, indicates that within-firm wage dispersion is higher in sector-regions pairs featuring more dynamic technological change. Also, it corroborates that the estimates of the innovation dummy coefficients are not inflated from possibly confounding factors related to local and sectoral markets for researchers.

In Table 4 we show the estimates for the alternative specification taking the (adjusted) wage-gap between managers and low-layer occupations $w^{d 2}$ as the dependent variable. The results reveal sharp differences compared to the analysis of the $90^{\text {th }}$-to- $10^{\text {th }}$ percentile wage-gap, corroborating that the two dispersion measures are indeed capturing different dimensions of within-firm wage inequality. ${ }^{3}$ The key finding is indeed that the innovation dummy has a negative and significant coefficient, essentially along

\footnotetext{
${ }^{3}$ Recall that the two exercises are not fully comparable, since here the sample includes firms that have at least one manager and one employee in the ISCO categories 7, 8 or 9 , as it is implicit in the definition of $w^{d 2}$.
} 
Table 4: Innovation and within-firm wage dispersion, managers vs. low-layer employees.

\begin{tabular}{|c|c|c|c|c|c|c|}
\hline \multirow{3}{*}{ Innov } & \multirow[b]{2}{*}{ OLS } & \multicolumn{5}{|c|}{ Simultaneous Quantile Regression } \\
\hline & & q10 & $\mathrm{q} 25$ & q50 & $\mathrm{q} 75$ & q90 \\
\hline & $\begin{array}{c}-0.0481^{* * *} \\
(0.0120)\end{array}$ & $\begin{array}{c}-0.0131 \\
(0.0173)\end{array}$ & $\begin{array}{c}-0.0357^{*} \\
(0.0169)\end{array}$ & $\begin{array}{c}-0.0568^{* * *} \\
(0.0143)\end{array}$ & $\begin{array}{c}-0.0730^{* * *} \\
(0.0162)\end{array}$ & $\begin{array}{c}-0.0932^{* * *} \\
(0.0239)\end{array}$ \\
\hline Medium-large firm & $\begin{array}{l}0.0389^{* *} \\
(0.0126)\end{array}$ & $\begin{array}{l}0.0679^{* * *} \\
(0.0165)\end{array}$ & $\begin{array}{l}0.0524^{* * *} \\
(0.0145)\end{array}$ & $\begin{array}{c}0.0196 \\
(0.0116)\end{array}$ & $\begin{array}{c}0.0134 \\
(0.0189)\end{array}$ & $\begin{array}{c}0.0248 \\
(0.0240)\end{array}$ \\
\hline Innov index & $\begin{array}{c}-0.191^{*} \\
(0.0846)\end{array}$ & $\begin{array}{c}-0.343^{* *} \\
(0.119)\end{array}$ & $\begin{array}{c}-0.294^{* * *} \\
(0.0774)\end{array}$ & $\begin{array}{c}-0.170 \\
(0.131)\end{array}$ & $\begin{array}{c}-0.116 \\
(0.157)\end{array}$ & $\begin{array}{c}-0.303 \\
(0.199)\end{array}$ \\
\hline Public firms & $\begin{array}{c}-0.0539^{*} \\
(0.0244)\end{array}$ & $\begin{array}{c}0.0278 \\
(0.0401)\end{array}$ & $\begin{array}{c}-0.0135 \\
(0.0340)\end{array}$ & $\begin{array}{c}-0.0127 \\
(0.0353)\end{array}$ & $\begin{array}{c}-0.0589 \\
(0.0437)\end{array}$ & $\begin{array}{c}-0.116^{* * *} \\
(0.0336)\end{array}$ \\
\hline No coll. agr. & $\begin{array}{l}0.180^{* * *} \\
(0.0132)\end{array}$ & $\begin{array}{l}0.0848^{* * *} \\
(0.0199)\end{array}$ & $\begin{array}{l}0.115^{* * *} \\
(0.0164)\end{array}$ & $\begin{array}{l}0.188^{* * *} \\
(0.0170)\end{array}$ & $\begin{array}{c}0.232^{* * *} \\
(0.0230)\end{array}$ & $\begin{array}{c}0.253^{* * *} \\
(0.0431)\end{array}$ \\
\hline \multicolumn{7}{|l|}{ Modal age empl. } \\
\hline $14-19$ & $\begin{array}{c}0.0962 \\
(0.133)\end{array}$ & $\begin{array}{c}0.125 \\
(0.204)\end{array}$ & $\begin{array}{c}-0.00766 \\
(0.0629)\end{array}$ & $\begin{array}{c}-0.167 \\
(0.213)\end{array}$ & $\begin{array}{c}0.295 \\
(0.293)\end{array}$ & $\begin{array}{c}0.233 \\
(0.374)\end{array}$ \\
\hline $20-29$ & $\begin{array}{c}-0.00151 \\
(0.0200)\end{array}$ & $\begin{array}{c}-0.0252 \\
(0.0332)\end{array}$ & $\begin{array}{c}0.00293 \\
(0.0304)\end{array}$ & $\begin{array}{c}-0.0253 \\
(0.0257)\end{array}$ & $\begin{array}{r}0.00881 \\
(0.0228)\end{array}$ & $\begin{array}{c}-0.0122 \\
(0.0441)\end{array}$ \\
\hline $40-49$ & $\begin{array}{c}0.0267 \\
(0.0139)\end{array}$ & $\begin{array}{c}0.0464 \\
(0.0245)\end{array}$ & $\begin{array}{c}0.0354^{*} \\
(0.0168)\end{array}$ & $\begin{array}{c}0.0185 \\
(0.0171)\end{array}$ & $\begin{array}{c}0.0320 \\
(0.0184)\end{array}$ & $\begin{array}{c}-0.00836 \\
(0.0332)\end{array}$ \\
\hline $50-59$ & $\begin{array}{l}0.0628^{* * *} \\
(0.0168)\end{array}$ & $\begin{array}{l}0.0598^{* *} \\
(0.0202)\end{array}$ & $\begin{array}{r}0.0562^{*} \\
(0.0227)\end{array}$ & $\begin{array}{c}0.0502 \\
(0.0293)\end{array}$ & $\begin{array}{l}0.0863^{* *} \\
(0.0275)\end{array}$ & $\begin{array}{c}0.0576 \\
(0.0405)\end{array}$ \\
\hline $60+$ & $\begin{array}{c}0.0914 \\
(0.106)\end{array}$ & $\begin{array}{c}0.200 \\
(0.234)\end{array}$ & $\begin{array}{c}0.0161 \\
(0.229)\end{array}$ & $\begin{array}{c}0.108 \\
(0.220)\end{array}$ & $\begin{array}{c}0.113 \\
(0.126)\end{array}$ & $\begin{array}{c}-0.0856 \\
(0.127)\end{array}$ \\
\hline$\%$ empl. tertiary ed. & $\begin{array}{c}-0.00132^{* *} \\
(0.000431)\end{array}$ & $\begin{array}{r}-0.000884 \\
(0.000625)\end{array}$ & $\begin{array}{r}-0.000538 \\
(0.000384)\end{array}$ & $\begin{array}{c}-0.00137^{*} \\
(0.000609)\end{array}$ & $\begin{array}{c}-0.00154^{* *} \\
(0.000529)\end{array}$ & $\begin{array}{r}-0.00221^{* *} \\
(0.000784)\end{array}$ \\
\hline Average tenure empl. & $\begin{array}{c}-0.00616^{* * *} \\
(0.00111)\end{array}$ & $\begin{array}{c}-0.00175 \\
(0.00158)\end{array}$ & $\begin{array}{c}-0.00341^{*} \\
(0.00153)\end{array}$ & $\begin{array}{c}-0.00659^{* * *} \\
(0.00127)\end{array}$ & $\begin{array}{c}-0.0106^{* * *} \\
(0.00131)\end{array}$ & $\begin{array}{c}-0.0133^{* * *} \\
(0.00156)\end{array}$ \\
\hline$\%$ ISCO $1-2$ & $\begin{array}{r}-0.000997^{*} \\
(0.000508)\end{array}$ & $\begin{array}{c}-0.000471 \\
(0.000653)\end{array}$ & $\begin{array}{c}-0.000852 \\
(0.000512)\end{array}$ & $\begin{array}{c}-0.00125^{*} \\
(0.000566)\end{array}$ & $\begin{array}{r}-0.00188^{* *} \\
(0.000655)\end{array}$ & $\begin{array}{c}-0.000537 \\
(0.000955)\end{array}$ \\
\hline$\%$ Perm. contracts & $\begin{array}{c}0.000570 \\
(0.000545)\end{array}$ & $\begin{array}{c}0.00122 \\
(0.000751)\end{array}$ & $\begin{array}{c}0.00109 \\
(0.000573)\end{array}$ & $\begin{array}{c}0.00140^{*} \\
(0.000590)\end{array}$ & $\begin{array}{c}0.000595 \\
(0.000578)\end{array}$ & $\begin{array}{c}-0.000676 \\
(0.00170)\end{array}$ \\
\hline$\%$ Males & $\begin{array}{c}-0.00107 * * * \\
(0.000289)\end{array}$ & $\begin{array}{c}-0.000468 \\
(0.000464)\end{array}$ & $\begin{array}{c}-0.000790 \\
(0.000428)\end{array}$ & $\begin{array}{c}-0.00102^{* * *} \\
(0.000293)\end{array}$ & $\begin{array}{r}-0.00104^{* *} \\
(0.000329)\end{array}$ & $\begin{array}{c}-0.00155^{*} \\
(0.000703)\end{array}$ \\
\hline Constant & $\begin{array}{c}0.0887 \\
(0.0821) \\
\end{array}$ & $\begin{array}{c}-0.702^{* * *} \\
(0.144) \\
\end{array}$ & $\begin{array}{c}-0.256^{* *} \\
(0.0828)\end{array}$ & $\begin{array}{r}-0.0596 \\
(0.127)\end{array}$ & $\begin{array}{l}0.383^{* * *} \\
(0.101)\end{array}$ & $\begin{array}{l}1.103^{* * *} \\
(0.179)\end{array}$ \\
\hline Observations & 7710 & 7710 & & & & \\
\hline Sector fixed effects & Yes & Yes & & & & \\
\hline Country fixed effects & Yes & Yes & & & & \\
\hline
\end{tabular}

Standard errors in parentheses, clustered at the firm level. Significance levels: ${ }^{*} p<0.05,{ }^{* *} p<0.01,{ }^{* * *} p<0.001$ 
the entire wage dispersion distribution. Thus, the wage inequality between managerial positions and more elementary occupations is smaller in innovative vis a vis non-innovative firms. Notice that such "equality-enhancing" effect of innovation is sizeably stronger among less egalitarian firms featuring comparatively larger wage-gaps between managers and lower-layers jobs, as indeed the coefficient estimates increase in magnitude from the bottom to the top quantiles.

Concerning the firm-level controls, firm size features a positive relation with wage dispersion among more egalitarian firms in the bottom quantiles. Publicly controlled firms show, on average (in the OLS estimates) a lower wage dispersion among professions, but such a result is entirely due to the strong difference emerging among unequal firms at the $90^{\text {th }}$ percentile. We also observe that firms that do not apply any form of collective bargaining tend to display a higher managers vs. low-layers wage-gap, and the result is more marked among firms in the top quantiles.

Next, personal and structural workforce characteristics also play some significant role. Concerning age, the wage-gap increases with the share of relatively older workers (50-59 years old), suggesting that this cohort of workers, as it is intuitive, is more likely employed in managerial positions, as compared to the base category of 30-39 years old employees. Furthermore, tenure in employment and the share of male workers tend to be negatively associated with the professional wage-gap in most quantiles. These results mimic the analysis of the $90^{\text {th }}$-to- $10^{\text {th }}$ percentile wage-gap, and a similar interpretation of compositional effects can be put forward. A qualification could be that the lower wage dispersion associated with having more males and more tenured workers can be linked to the well-known fact that women and short-tenured employees are less likely to be employed in managerial positions. We also find negative coefficients on the share of workers with tertiary education, in most quantiles. Thus, differently from the analysis of $w^{d 1}$, compositional effects are such that firms with more educated workers feature reduced inequalities in the wage-gap between managerial and elementary occupations, in line with the intuition that higher education levels are more concentrated among managers than among lower-layers employees. The coefficients on the share of professional workers and permanent contracts are largely not significant.

Finally, we still confirm the relevance of sector and geographical intensity of innovation, as summarised by the innovation index, although its significance is lost in the right part of the support of the professional wage-gap. When significant, the sign is negative, in agreement with the inequalityreducing effect of innovation suggested by the firm-level innovation dummy.

\subsection{The mediating role of firm size}

We next report the estimates of the models with innovation-size interaction. Recall from Eq. (2) that a dummy for small-large firms is included in the set of controls $\mathbf{Z}$. Accordingly, the coefficients of primary interest in disentangling the role of innovation are the coefficient $\beta$ on the Innov dummy, telling whether dispersion is higher in innovative small firms as compared to the control group of noninnovative small firms, and the interaction coefficient $\delta$, accounting for potential differences across small vs. medium-large innovative firms.

In Table 5 we take the $90^{\text {th }}$-to- $10^{\text {th }}$ percentile wage ratio as the dependent variable. We find two main patterns. On the one hand, for small firms, we estimate a positive association between innovation and wage inequality from the bottom quantiles to the median of the distribution of $w^{d 1}$, whereas innovation is "equality-enhancing" (negative coefficient on Innov) in the top extreme, that 
Table 5: Innovation and within-firm wage dispersion as the $90^{\text {th }}$-to- $10^{\text {th }}$ percentile wage ratio, model with firm size-innovation interaction.

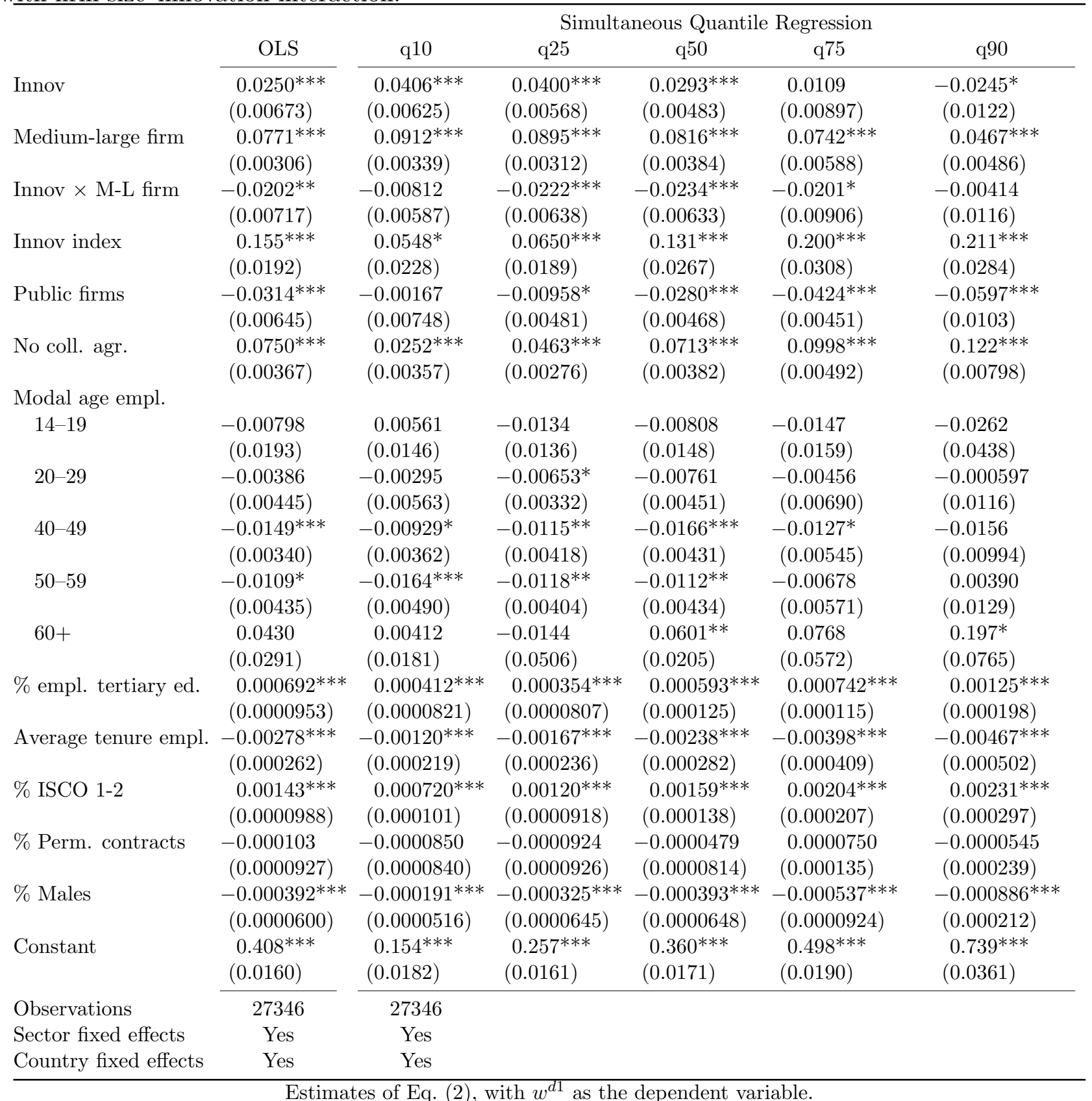

Standard errors in parentheses, clustered at the firm level. Significance levels: ${ }^{*} p<0.05,{ }^{* *} p<0.01,{ }^{* * *} p<0.001$ 
is among relatively more unequal small firms. On the other hand, the interaction term displays a negative and significant coefficient in the central quantiles (at $q_{25}, q_{50}, q_{75}$ ). Thus, in this part of the wage dispersion distribution, wage inequalities are reduced in innovative medium-large firms as compared to innovative small firms. There is no statistical difference, instead, in the bottom $\left(q_{10}\right)$ and top $\left(q_{90}\right)$ quantiles, that is for relatively more egalitarian and relatively more unequal firms. The estimates of the coefficients on firm-level controls, workforce characteristics and innovation index are all in agreement with the patterns observed for the baseline model without size-technology interaction.

Table 6: Innovation and within-firm wage dispersion comparing managers vs. low-layer employees, model with firm size-innovation interaction.

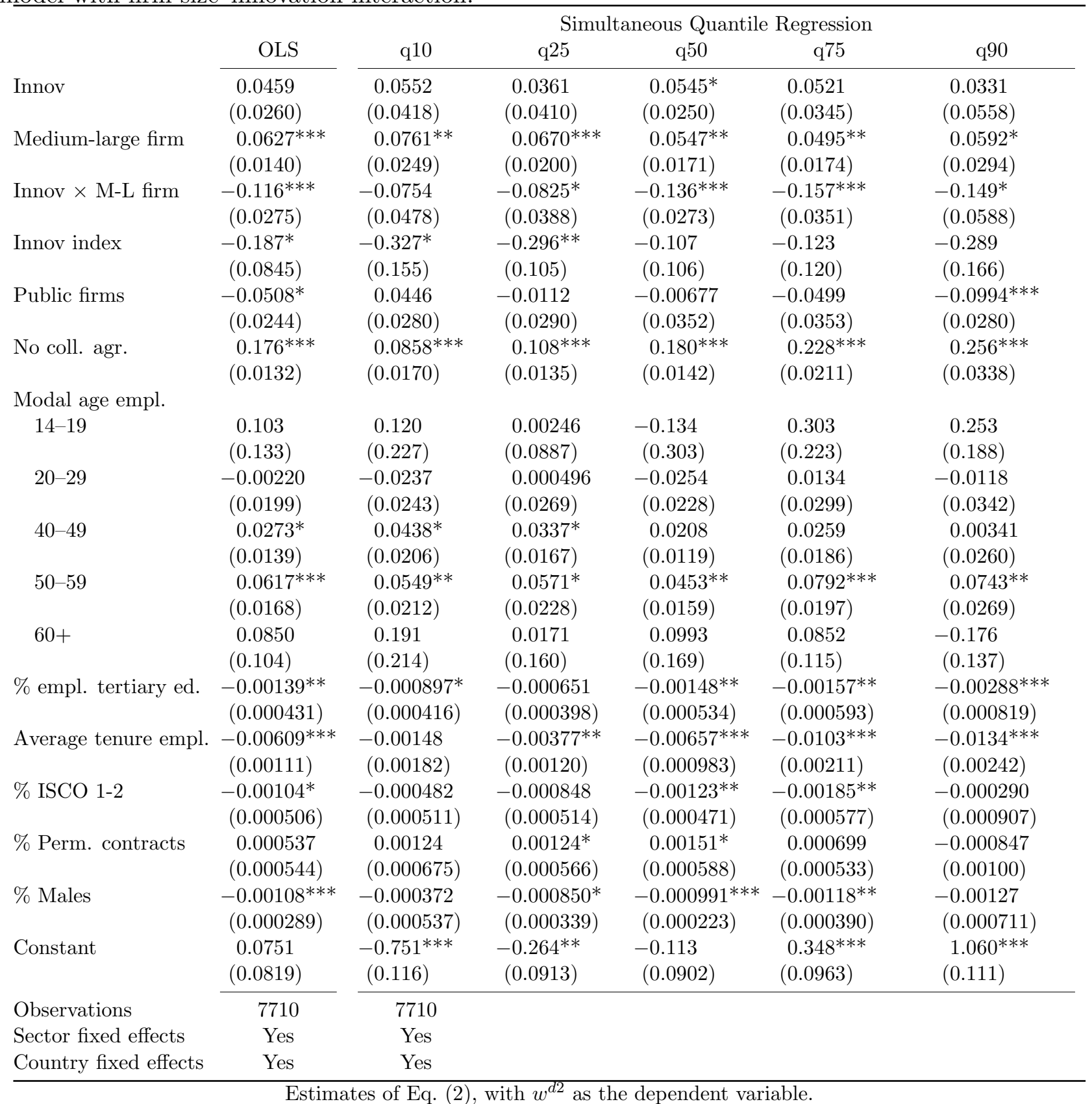

Standard errors in parentheses, clustered at the firm level. Significance levels: ${ }^{*} p<0.05,{ }^{* *} p<0.01,{ }^{* * *} p<0.001$

The results partially differ when we estimate the model taking the managers vs. low-layer workers wage gap $w^{d 2}$ as the dependent variable, reported in Table 6 . We find, first, that small innovative firms 
do not show any statistically significant difference in wage dispersion as compared to the control group of small non-innovators. Only the coefficient estimated for the median of $w^{d 2}$ is barely significant, indeed. Second, and in line with results for the $90^{\text {th }}$-to- $10^{\text {th }}$ percentile wage ratio, we find that the coefficients on the interaction terms are negative and statistically different from zero in most quantiles, apart from the first decile. Thus, medium-large firms display lower professional wage-gaps that small innovators. Finally, concerning the controls, also in this case the estimates tend to agree with the findings documented in the model without innovation-size interaction.

\section{Robustness checks}

While the relatively rich set of controls should cure most of potential omitted variable bias, our main estimates could potentially suffer from a form of reverse causality. Indeed, the presence of researchers in a given firm (exploited to build our main explanatory variable Innov) may itself be driven by the wage dispersion in the firm, as highly-educated professional researchers may seek employment in firms that have a higher human capital wage premium. ${ }^{4}$ In order to account for this potential problem, we apply a standard procedure commonly followed in the literature on wage dispersion (Card and De La Rica, 2006; Daouli et al., 2013). We run a first-step Probit on the probability that a firm in our sample is innovative (i.e. employs at least one researcher), using the following set of predictors: the share of university graduates among employees in the firm, the share of managers and professionals, the share of employees with permanent contracts, the modal age of employees, the share of males, the mean tenure of employees, firm size, and whether the firm is publicly-owned. Then, the propensity scores (i.e., the fitted values) from the first step Probit are included in estimating Eq. 1 and Eq. 2 as a further firm-level regressor, additional to the Innov dummy, the interaction terms and the other controls.

In Table 7 and Table 8 we show the estimates for the baseline model without innovation-size interactions. The propensity score term displays significant coefficients, confirming the validity of the procedure, but its introduction only marginally affects the signs and patterns of significance of the Innov dummy coefficients. First, concerning the $90^{\text {th }}$-to- $10^{\text {th }}$ percentile wage ratio (in Table 7 ), we confirm that innovation has a general positive association with wage dispersion from the bottom quantiles to the median of the wage dispersion distribution. The main difference with the baseline results from the previous Section is that we do not find anymore that innovation is equality-enhancing in the top quantiles of $w^{d 1}$. Second, concerning the specification for the professional wage-gap $w^{d 2}$ (in Table 8), we confirm our main conclusion that innovative firms display smaller wage dispersion between managers and low-layers occupations. If any, the only effect of adding the propensity score term is to weaken the magnitude of the coefficients on the Innov dummy.

Next, in Table 9 and Table 10 we re-estimate the models that also include the interaction between innovation and firm size. Also in this case, the propensity score term displays explanatory power, but it does not significantly affect the conclusions achieved from the baseline estimates presented in the previous Section. Indeed, we obtain that the $90^{\text {th }}$-to- $10^{\text {th }}$ wage ratio (see Table 9 ) is higher in small innovative firms than in the control group of small non-innovators in the left part of the distribution (cf. the coefficient on the Innov dummy alone), and that innovation in medium-large firms tends to

\footnotetext{
${ }^{4}$ And this beyond observed factors that influence individual wages, already controlled for by taking the residual wage from the Mincerian regression in Eq. (3).
} 
Table 7: Innovation and within-firm wage dispersion as the $90^{\text {th }}$-to- $10^{\text {th }}$ percentile wage ratio, estimates with propensity score correction.

\begin{tabular}{|c|c|c|c|c|c|c|}
\hline & \multirow[b]{2}{*}{ OLS } & \multicolumn{5}{|c|}{ Simultaneous Quantile Regression } \\
\hline & & q10 & q25 & q50 & q75 & q90 \\
\hline \multirow[t]{2}{*}{ Innov } & $0.0140^{* * *}$ & $0.0343^{* * *}$ & $0.0241^{* * *}$ & $0.0163^{* * *}$ & -0.000142 & -0.0180 \\
\hline & $(0.00369)$ & $(0.00251)$ & $(0.00354)$ & $(0.00268)$ & $(0.00489)$ & $(0.00975)$ \\
\hline \multirow[t]{2}{*}{ Prob. innov } & $-0.0711^{* * *}$ & 0.0121 & $-0.0218^{*}$ & $-0.0532^{* * *}$ & $-0.0934^{* * *}$ & $-0.167^{* * *}$ \\
\hline & $(0.0148)$ & $(0.0151)$ & $(0.0108)$ & $(0.0119)$ & $(0.0192)$ & $(0.0249)$ \\
\hline \multirow[t]{2}{*}{ Medium-large firm } & $0.0818^{* * *}$ & $0.0878^{* * *}$ & $0.0886^{* * *}$ & $0.0838^{* * *}$ & $0.0820^{* * *}$ & $0.0635^{* * *}$ \\
\hline & $(0.00333)$ & $(0.00373)$ & $(0.00314)$ & $(0.00323)$ & $(0.00610)$ & $(0.00641)$ \\
\hline \multirow[t]{2}{*}{ Innov index } & $0.153^{* * *}$ & $0.0553^{*}$ & $0.0683^{* * *}$ & $0.124^{* * *}$ & $0.203^{* * *}$ & $0.206^{* * *}$ \\
\hline & $(0.0192)$ & $(0.0215)$ & $(0.0190)$ & $(0.0251)$ & $(0.0341)$ & $(0.0467)$ \\
\hline \multirow[t]{2}{*}{ Public firms } & $-0.0312^{* * *}$ & -0.00229 & -0.00821 & $-0.0272^{* * *}$ & $-0.0417^{* * *}$ & $-0.0602^{* * *}$ \\
\hline & $(0.00644)$ & $(0.00693)$ & $(0.00553)$ & $(0.00423)$ & $(0.00948)$ & $(0.00733)$ \\
\hline \multirow[t]{2}{*}{ No coll. agr. } & $0.0707^{* * *}$ & $0.0260^{* * *}$ & $0.0453^{* * *}$ & $0.0701^{* * *}$ & $0.0939^{* * *}$ & $0.111^{* * *}$ \\
\hline & $(0.00375)$ & $(0.00359)$ & $(0.00356)$ & $(0.00452)$ & $(0.00539)$ & $(0.0128)$ \\
\hline \multicolumn{7}{|l|}{ Modal age empl. } \\
\hline \multirow[t]{2}{*}{$14-19$} & -0.0182 & 0.00851 & -0.0189 & -0.0136 & $-0.0329^{*}$ & -0.0502 \\
\hline & $(0.0195)$ & $(0.0144)$ & $(0.0219)$ & $(0.0223)$ & $(0.0158)$ & $(0.0440)$ \\
\hline \multirow[t]{2}{*}{$20-29$} & -0.00730 & -0.00283 & $-0.00662^{*}$ & $-0.0109^{*}$ & -0.0116 & -0.00973 \\
\hline & $(0.00449)$ & $(0.00382)$ & $(0.00309)$ & $(0.00518)$ & $(0.00797)$ & $(0.0118)$ \\
\hline \multirow[t]{2}{*}{$40-49$} & $-0.0147 * * *$ & $-0.00887^{* *}$ & $-0.0117^{* * *}$ & $-0.0160 * * *$ & $-0.0126^{*}$ & $-0.0181^{*}$ \\
\hline & $(0.00340)$ & $(0.00283)$ & $(0.00223)$ & $(0.00367)$ & $(0.00508)$ & $(0.00802)$ \\
\hline \multirow[t]{2}{*}{$50-59$} & $-0.0114^{* *}$ & $-0.0157^{* * *}$ & $-0.0114^{* * *}$ & $-0.0110^{*}$ & -0.00681 & -0.0000157 \\
\hline & $(0.00435)$ & $(0.00455)$ & $(0.00305)$ & $(0.00442)$ & $(0.00544)$ & $(0.0124)$ \\
\hline \multirow[t]{2}{*}{$60+$} & 0.0383 & 0.00727 & -0.0196 & 0.0535 & 0.0839 & 0.175 \\
\hline & $(0.0290)$ & $(0.0120)$ & $(0.0301)$ & $(0.0379)$ & $(0.0735)$ & $(0.0921)$ \\
\hline \multirow[t]{2}{*}{ \% empl. tertiary ed. } & $0.000983^{* * *}$ & $0.000343^{* *}$ & $0.000419^{* * *}$ & $0.000823^{* * *}$ & $0.00120^{* * *}$ & $0.00194^{* * *}$ \\
\hline & $(0.000114)$ & $(0.000131)$ & $(0.0000966)$ & $(0.000107)$ & $(0.000142)$ & $(0.000228)$ \\
\hline \multirow[t]{2}{*}{ Average tenure empl. } & $-0.00231^{* * *}$ & $-0.00132^{* * *}$ & $-0.00152^{* * *}$ & $-0.00198^{* * *}$ & $-0.00324^{* * *}$ & $-0.00324^{* * *}$ \\
\hline & $(0.000285)$ & $(0.000221)$ & $(0.000295)$ & $(0.000326)$ & $(0.000444)$ & $(0.000720)$ \\
\hline \multirow[t]{2}{*}{$\%$ ISCO 1-2 } & $0.00162^{* * *}$ & $0.000726^{* * *}$ & $0.00128^{* * *}$ & $0.00172^{* * *}$ & $0.00223^{* * *}$ & $0.00272^{* * *}$ \\
\hline & $(0.000104)$ & $(0.0000812)$ & $(0.000106)$ & $(0.000110)$ & $(0.0000930)$ & $(0.000318)$ \\
\hline \multirow[t]{2}{*}{$\%$ Perm. contracts } & -0.000169 & -0.0000828 & -0.000101 & -0.000117 & -0.0000426 & -0.000154 \\
\hline & $(0.0000936)$ & $(0.0000813)$ & $(0.000101)$ & $(0.0000937)$ & $(0.000171)$ & $(0.000262)$ \\
\hline \multirow[t]{2}{*}{$\%$ Males } & $-0.000282^{* * *}$ & $-0.000221^{* * *}$ & $-0.000302^{* * *}$ & $-0.000300^{* * *}$ & $-0.000407^{* * *}$ & $-0.000561^{* *}$ \\
\hline & $(0.0000641)$ & $(0.0000449)$ & $(0.0000557)$ & $(0.0000508)$ & $(0.000101)$ & $(0.000204)$ \\
\hline \multirow[t]{2}{*}{ Constant } & $0.403^{* * *}$ & $0.157^{* * *}$ & $0.254^{* * *}$ & $0.357^{* * *}$ & $0.488^{* * *}$ & $0.711^{* * *}$ \\
\hline & $(0.0161)$ & $(0.0161)$ & $(0.0179)$ & $(0.0180)$ & $(0.0278)$ & $(0.0393)$ \\
\hline Observations & 27346 & 27346 & & & & \\
\hline Sector fixed effects & Yes & Yes & & & & \\
\hline Country fixed effects & Yes & Yes & & & & \\
\hline
\end{tabular}

Estimates of Eq. (1), with $w^{d 1}$ as the dependent variable.

Regressors also include fitted probabilities (Prob.innov.) from a Probit on innovation status.

Standard errors in parentheses, clustered at the firm level. Significance levels: ${ }^{*} p<0.05,{ }^{* *} p<0.01,{ }^{* * *} p<0.001$ 
Table 8: Innovation and within-firm wage dispersion comparing managers vs. low-layer employees, estimates with propensity score correction.

\begin{tabular}{|c|c|c|c|c|c|c|}
\hline & \multirow[b]{2}{*}{ OLS } & \multicolumn{5}{|c|}{ Simultaneous Quantile Regression } \\
\hline & & q10 & $\mathrm{q} 25$ & q50 & $\mathrm{q} 75$ & q90 \\
\hline Innov & $\begin{array}{c}-0.0320^{* *} \\
(0.0122)\end{array}$ & $\begin{array}{c}-0.00516 \\
(0.0118)\end{array}$ & $\begin{array}{c}-0.0241 \\
(0.0129)\end{array}$ & $\begin{array}{c}-0.0475^{* * *} \\
(0.0104)\end{array}$ & $\begin{array}{c}-0.0569^{* * *} \\
(0.0167)\end{array}$ & $\begin{array}{c}-0.0706^{* * *} \\
(0.0189)\end{array}$ \\
\hline Prob. innov & $\begin{array}{c}-0.524^{* * *} \\
(0.0623)\end{array}$ & $\begin{array}{c}-0.242 \\
(0.129)\end{array}$ & $\begin{array}{c}-0.354^{* * *} \\
(0.0897)\end{array}$ & $\begin{array}{c}-0.554^{* * *} \\
(0.0800)\end{array}$ & $\begin{array}{c}-0.698^{* * *} \\
(0.0782)\end{array}$ & $\begin{array}{c}-0.663^{* * *} \\
(0.104)\end{array}$ \\
\hline Innov index & $\begin{array}{c}-0.196^{*} \\
(0.0844)\end{array}$ & $\begin{array}{c}-0.321^{* *} \\
(0.117)\end{array}$ & $\begin{array}{c}-0.320^{* *} \\
(0.0977)\end{array}$ & $\begin{array}{c}-0.112 \\
(0.105)\end{array}$ & $\begin{array}{c}-0.0591 \\
(0.127)\end{array}$ & $\begin{array}{c}-0.223 \\
(0.160)\end{array}$ \\
\hline Medium-large firm & $\begin{array}{l}0.125^{* * *} \\
(0.0161)\end{array}$ & $\begin{array}{l}0.114^{* * *} \\
(0.0274)\end{array}$ & $\begin{array}{l}0.110^{* * *} \\
(0.0155)\end{array}$ & $\begin{array}{l}0.116^{* * *} \\
(0.0216)\end{array}$ & $\begin{array}{l}0.122^{* * *} \\
(0.0188)\end{array}$ & $\begin{array}{l}0.130^{* * *} \\
(0.0266)\end{array}$ \\
\hline Public firms & $\begin{array}{c}-0.0676^{* *} \\
(0.0245)\end{array}$ & $\begin{array}{c}0.0210 \\
(0.0296)\end{array}$ & $\begin{array}{c}-0.0294 \\
(0.0353)\end{array}$ & $\begin{array}{c}-0.0315 \\
(0.0257)\end{array}$ & $\begin{array}{c}-0.0689^{*} \\
(0.0312)\end{array}$ & $\begin{array}{r}-0.134^{* *} \\
(0.0469)\end{array}$ \\
\hline No coll. agr. & $\begin{array}{l}0.155^{* * *} \\
(0.0135)\end{array}$ & $\begin{array}{l}0.0704^{* *} \\
(0.0217)\end{array}$ & $\begin{array}{l}0.0947^{* * *} \\
(0.0188)\end{array}$ & $\begin{array}{l}0.157^{* * *} \\
(0.0168)\end{array}$ & $\begin{array}{c}0.195^{* * *} \\
(0.0210)\end{array}$ & $\begin{array}{l}0.229^{* * *} \\
(0.0369)\end{array}$ \\
\hline Modal age empl. & & & & & & \\
\hline $14-19$ & $\begin{array}{c}0.0246 \\
(0.130)\end{array}$ & $\begin{array}{c}0.122 \\
(0.213)\end{array}$ & $\begin{array}{c}-0.0668 \\
(0.0985)\end{array}$ & $\begin{array}{c}-0.155 \\
(0.217)\end{array}$ & $\begin{array}{c}0.197 \\
(0.273)\end{array}$ & $\begin{array}{c}0.173 \\
(0.268)\end{array}$ \\
\hline $20-29$ & $\begin{array}{c}-0.0284 \\
(0.0204)\end{array}$ & $\begin{array}{c}-0.0405 \\
(0.0304)\end{array}$ & $\begin{array}{c}-0.0227 \\
(0.0270)\end{array}$ & $\begin{array}{c}-0.0461^{* *} \\
(0.0156)\end{array}$ & $\begin{array}{c}-0.0318 \\
(0.0262)\end{array}$ & $\begin{array}{c}-0.0441 \\
(0.0423)\end{array}$ \\
\hline $40-49$ & $\begin{array}{c}0.0375^{* *} \\
(0.0139)\end{array}$ & $\begin{array}{c}0.0542^{*} \\
(0.0257)\end{array}$ & $\begin{array}{l}0.0454^{* * *} \\
(0.0125)\end{array}$ & $\begin{array}{l}0.0397^{* *} \\
(0.0125)\end{array}$ & $\begin{array}{c}0.0359^{*} \\
(0.0171)\end{array}$ & $\begin{array}{c}-0.00572 \\
(0.0289)\end{array}$ \\
\hline $50-59$ & $\begin{array}{l}0.0654^{* * *} \\
(0.0167)\end{array}$ & $\begin{array}{c}0.0620^{*} \\
(0.0313)\end{array}$ & $\begin{array}{l}0.0669^{* * *} \\
(0.0198)\end{array}$ & $\begin{array}{l}0.0617^{* * *} \\
(0.0171)\end{array}$ & $\begin{array}{l}0.0746^{* * *} \\
(0.0192)\end{array}$ & $\begin{array}{c}0.0614^{*} \\
(0.0294)\end{array}$ \\
\hline $60+$ & $\begin{array}{c}0.0270 \\
(0.108)\end{array}$ & $\begin{array}{c}0.143 \\
(0.234)\end{array}$ & $\begin{array}{l}0.00388 \\
(0.202)\end{array}$ & $\begin{array}{c}0.0749 \\
(0.125)\end{array}$ & $\begin{array}{c}0.0264 \\
(0.0987)\end{array}$ & $\begin{array}{l}-0.162 \\
(0.0974)\end{array}$ \\
\hline \% empl. tertiary ed. & $\begin{array}{c}0.00178^{* *} \\
(0.000563)\end{array}$ & $\begin{array}{c}0.000326 \\
(0.00108)\end{array}$ & $\begin{array}{c}0.00148^{*} \\
(0.000708)\end{array}$ & $\begin{array}{c}0.00202^{*} \\
(0.000840)\end{array}$ & $\begin{array}{c}0.00286^{* *} \\
(0.000993)\end{array}$ & $\begin{array}{c}0.00202 \\
(0.00146)\end{array}$ \\
\hline Average tenure empl. & $\begin{array}{c}-0.00172 \\
(0.00125)\end{array}$ & $\begin{array}{c}0.000213 \\
(0.00179)\end{array}$ & $\begin{array}{c}-0.00143 \\
(0.00179)\end{array}$ & $\begin{array}{c}-0.00249 \\
(0.00135)\end{array}$ & $\begin{array}{c}-0.00400^{* *} \\
(0.00139)\end{array}$ & $\begin{array}{c}-0.00703^{* *} \\
(0.00264)\end{array}$ \\
\hline$\%$ ISCO $1-2$ & $\begin{array}{c}-0.0000488 \\
(0.000524)\end{array}$ & $\begin{array}{c}0.0000648 \\
(0.000736)\end{array}$ & $\begin{array}{r}-0.000228 \\
(0.000596)\end{array}$ & $\begin{array}{c}0.0000391 \\
(0.000468)\end{array}$ & $\begin{array}{r}-0.000776 \\
(0.000579)\end{array}$ & $\begin{array}{c}0.0000317 \\
(0.00139)\end{array}$ \\
\hline$\%$ Perm. contracts & $\begin{array}{c}-0.0000833 \\
(0.000549)\end{array}$ & $\begin{array}{c}0.000900 \\
(0.000708)\end{array}$ & $\begin{array}{c}0.000632 \\
(0.000583)\end{array}$ & $\begin{array}{c}0.000513 \\
(0.000555)\end{array}$ & $\begin{array}{r}-0.000227 \\
(0.000605)\end{array}$ & $\begin{array}{c}-0.00115 \\
(0.00129)\end{array}$ \\
\hline$\%$ Males & $\begin{array}{c}0.00000734 \\
(0.000321)\end{array}$ & $\begin{array}{c}0.000189 \\
(0.000450)\end{array}$ & $\begin{array}{c}-0.000159 \\
(0.000411)\end{array}$ & $\begin{array}{c}0.000230 \\
(0.000368)\end{array}$ & $\begin{array}{c}0.000441 \\
(0.000368)\end{array}$ & $\begin{array}{c}-0.000162 \\
(0.000620)\end{array}$ \\
\hline Constant & $\begin{array}{c}-0.0279 \\
(0.0829)\end{array}$ & $\begin{array}{c}-0.750^{* * *} \\
(0.141)\end{array}$ & $\begin{array}{c}-0.305^{* * *} \\
(0.0751)\end{array}$ & $\begin{array}{c}-0.211^{*} \\
(0.0907)\end{array}$ & $\begin{array}{c}0.193^{*} \\
(0.0949) \\
\end{array}$ & $\begin{array}{l}0.890^{* * *} \\
(0.159)\end{array}$ \\
\hline Observations & 7710 & 7710 & & & & \\
\hline Sector fixed effects & Yes & Yes & & & & \\
\hline Country fixed effects & Yes & Yes & & & & \\
\hline
\end{tabular}

Estimates of Eq. (1), with $w^{d 2}$ as the dependent variable.

Regressors also include fitted probabilities (Prob.innov.) from a Probit on innovation status.

Standard errors in parentheses, clustered at the firm level. Significance levels: ${ }^{*} p<0.05,{ }^{* *} p<0.01,{ }^{* * *} p<0.001$ 
Table 9: Innovation and within-firm wage dispersion as the $90^{\text {th }}$-to- $10^{\text {th }}$ percentile wage ratio, estimates with size-innovation interaction and propensity score correction.

\begin{tabular}{|c|c|c|c|c|c|c|}
\hline & & & Simulta & aneous Quantile & e Regression & \\
\hline & OLS & q10 & q25 & q50 & $\mathrm{q} 75$ & q90 \\
\hline Innov & $0.0236^{* * *}$ & $0.0420^{* * *}$ & $0.0392^{* * *}$ & $0.0279 * * *$ & 0.0104 & -0.0217 \\
\hline & $(0.00674)$ & $(0.00825)$ & $(0.00503)$ & $(0.00489)$ & $(0.00733)$ & $(0.0142)$ \\
\hline Medium-large firm & $0.0837^{* * *}$ & $0.0884^{* * *}$ & $0.0909^{* * *}$ & $0.0863^{* * *}$ & $0.0829^{* * *}$ & $0.0628^{* * *}$ \\
\hline & $(0.00345)$ & $(0.00348)$ & $(0.00335)$ & $(0.00467)$ & $(0.00493)$ & $(0.00778)$ \\
\hline Innov $\times$ M-L firm & -0.0143 & -0.0108 & $-0.0203^{* * *}$ & $-0.0176^{* * *}$ & $-0.0155^{*}$ & 0.00519 \\
\hline & $(0.00730)$ & $(0.00848)$ & $(0.00601)$ & $(0.00528)$ & $(0.00739)$ & $(0.0167)$ \\
\hline Prob. innov & $-0.0654^{* * *}$ & 0.0204 & -0.0122 & $-0.0448^{* *}$ & $-0.0848^{* * *}$ & $-0.169^{* * *}$ \\
\hline & $(0.0151)$ & $(0.0137)$ & $(0.0166)$ & $(0.0142)$ & $(0.0142)$ & $(0.0215)$ \\
\hline Innov index & $0.154^{* * *}$ & $0.0586^{*}$ & $0.0669^{* * *}$ & $0.124^{* * *}$ & $0.205^{* * *}$ & $0.206^{* * *}$ \\
\hline & $(0.0192)$ & $(0.0238)$ & $(0.0199)$ & $(0.0177)$ & $(0.0188)$ & $(0.0347)$ \\
\hline Public firms & $-0.0312^{* * *}$ & -0.00230 & -0.0100 & $-0.0287^{* * *}$ & $-0.0430^{* * *}$ & $-0.0609^{* * *}$ \\
\hline & $(0.00644)$ & $(0.00718)$ & $(0.00581)$ & $(0.00484)$ & $(0.0105)$ & $(0.0110)$ \\
\hline No coll. agr. & $0.0706^{* * *}$ & $0.0269 * * *$ & $0.0454^{* * *}$ & $0.0692^{* * *}$ & $0.0933^{* * *}$ & $0.111^{* * *}$ \\
\hline NIOdal a & $(0.00375)$ & $(0.00429)$ & $(0.00272)$ & $(0.00453)$ & $(0.00574)$ & $(0.00875)$ \\
\hline $14-19$ & -0.0168 & 0.0102 & -0.0163 & -0.0125 & -0.0305 & -0.0510 \\
\hline & $(0.0195)$ & $(0.0133)$ & $(0.0168)$ & $(0.0137)$ & $(0.0183)$ & $(0.0386)$ \\
\hline $20-29$ & -0.00700 & -0.00310 & -0.00717 & $-0.0102^{*}$ & -0.0101 & -0.0103 \\
\hline & $(0.00450)$ & $(0.00465)$ & $(0.00460)$ & $(0.00446)$ & $(0.00671)$ & $(0.0123)$ \\
\hline $40-49$ & $-0.0146^{* * *}$ & -0.00880 & $-0.0117^{* * *}$ & $-0.0163^{* * *}$ & -0.0122 & $-0.0186^{*}$ \\
\hline & $(0.00340)$ & $(0.00472)$ & $(0.00337)$ & $(0.00326)$ & $(0.00633)$ & $(0.00904)$ \\
\hline $50-59$ & $-0.0114^{* *}$ & $-0.0151^{* *}$ & $-0.0116^{* *}$ & $-0.0111^{*}$ & -0.00578 & -0.0000564 \\
\hline & $(0.00435)$ & $(0.00544)$ & $(0.00359)$ & $(0.00480)$ & $(0.00670)$ & $(0.00822)$ \\
\hline $60+$ & 0.0383 & 0.00219 & -0.0164 & 0.0546 & 0.0841 & 0.177 \\
\hline & $(0.0290)$ & $(0.0175)$ & $(0.0412)$ & $(0.0481)$ & $(0.0682)$ & $(0.0979)$ \\
\hline \% empl. tertiary ed. & $0.000954^{* * *}$ & $0.000293^{*}$ & $0.000401^{* * *}$ & $0.000788^{* * *}$ & $0.00116^{* * *}$ & $0.00194^{* * *}$ \\
\hline & $(0.000115)$ & $(0.000134)$ & $(0.000119)$ & $(0.0000884)$ & $(0.000147)$ & $(0.000233)$ \\
\hline Average tenure empl. & $-0.00234^{* * *}$ & $-0.00135^{* * *}$ & $-0.00162^{* * *}$ & $-0.00205^{* * *}$ & $-0.00331^{* * *}$ & $-0.00314^{* * *}$ \\
\hline & $(0.000285)$ & $(0.000240)$ & $(0.000270)$ & $(0.000318)$ & $(0.000461)$ & $(0.000553)$ \\
\hline$\%$ ISCO 1-2 & $0.00159^{* * *}$ & $0.000696^{* * *}$ & $0.00124^{* * *}$ & $0.00169^{* * *}$ & $0.00218^{* * *}$ & $0.00275^{* * *}$ \\
\hline & $(0.000105)$ & $(0.000146)$ & $(0.000141)$ & $(0.000106)$ & $(0.000129)$ & $(0.000250)$ \\
\hline$\%$ Perm. contracts & -0.000165 & -0.0000909 & -0.000111 & -0.0000957 & -0.0000206 & -0.000162 \\
\hline & $(0.0000936)$ & $(0.0000724)$ & $(0.0000751)$ & $(0.0000907)$ & $(0.000134)$ & $(0.000234)$ \\
\hline$\%$ Males & $-0.000290^{* * *}$ & $-0.000223^{* * *}$ & $-0.000306^{* * *}$ & $-0.000316^{* * *}$ & $-0.000413^{* * *}$ & $-0.000569^{* *}$ \\
\hline & $(0.0000642)$ & $(0.0000512)$ & $(0.0000514)$ & $(0.0000696)$ & $(0.000102)$ & $(0.000176)$ \\
\hline Constant & $0.402^{* * *}$ & $0.157^{* * *}$ & $0.256^{* * *}$ & $0.358^{* * *}$ & $0.489^{* * *}$ & $0.711^{* * *}$ \\
\hline & $(0.0161)$ & $(0.0148)$ & $(0.0160)$ & $(0.0129)$ & $(0.0163)$ & $(0.0286)$ \\
\hline Observations & 27346 & 27346 & & & & \\
\hline Sector fixed effects & Yes & Yes & & & & \\
\hline Country fixed effects & Yes & Yes & & & & \\
\hline
\end{tabular}

Estimates of Eq. (2), with $w^{d 1}$ as the dependent variable.

Regressors also include fitted probabilities (Prob.innov.) from a Probit on innovation status.

Standard errors in parentheses, clustered at the firm level. Significance levels: ${ }^{*} p<0.05,{ }^{* *} p<0.01,{ }^{* * *} p<0.001$ 
Table 10: Innovation and within-firm wage dispersion comparing managers vs. low-layer employees, estimates with size-innovation interaction and propensity score correction.

\begin{tabular}{|c|c|c|c|c|c|c|}
\hline & \multirow[b]{2}{*}{ OLS } & \multicolumn{5}{|c|}{ Simultaneous Quantile Regression } \\
\hline & & q10 & $\mathrm{q} 25$ & q50 & $\mathrm{q} 75$ & q90 \\
\hline \multirow[t]{2}{*}{ Innov } & 0.0348 & 0.0622 & 0.0246 & 0.0372 & 0.0254 & 0.0351 \\
\hline & $(0.0260)$ & $(0.0361)$ & $(0.0395)$ & $(0.0244)$ & $(0.0288)$ & $(0.0565)$ \\
\hline \multirow[t]{2}{*}{ Medium-large firm } & $0.136^{* * *}$ & $0.118^{* * *}$ & $0.118^{* * *}$ & $0.131^{* * *}$ & $0.142^{* * *}$ & $0.153^{* * *}$ \\
\hline & $(0.0168)$ & $(0.0255)$ & $(0.0242)$ & $(0.0133)$ & $(0.0193)$ & $(0.0332)$ \\
\hline \multirow[t]{2}{*}{ Innov $\times$ M-L firm } & $-0.0840^{* *}$ & -0.0712 & -0.0582 & $-0.0994^{* * *}$ & $-0.0973^{*}$ & $-0.137^{*}$ \\
\hline & $(0.0278)$ & $(0.0388)$ & $(0.0400)$ & $(0.0280)$ & $(0.0378)$ & $(0.0557)$ \\
\hline \multirow[t]{2}{*}{ Prob. innov } & $-0.491^{* * *}$ & $-0.230^{*}$ & $-0.351^{* * *}$ & $-0.544^{* * *}$ & $-0.683^{* * *}$ & $-0.612^{* * *}$ \\
\hline & $(0.0628)$ & $(0.103)$ & $(0.0942)$ & $(0.0530)$ & $(0.0798)$ & $(0.111)$ \\
\hline \multirow[t]{2}{*}{ Innov index } & $-0.193^{*}$ & $-0.326^{* *}$ & $-0.332^{* * *}$ & -0.0997 & -0.0782 & -0.220 \\
\hline & $(0.0844)$ & $(0.104)$ & $(0.0866)$ & $(0.0780)$ & $(0.113)$ & $(0.176)$ \\
\hline \multirow[t]{2}{*}{ Public firms } & $-0.0645^{* *}$ & 0.0279 & -0.0289 & -0.0317 & $-0.0762^{*}$ & $-0.127^{* * *}$ \\
\hline & $(0.0244)$ & $(0.0261)$ & $(0.0304)$ & $(0.0184)$ & $(0.0306)$ & $(0.0365)$ \\
\hline \multirow[t]{2}{*}{ No coll. agr. } & $0.153^{* * *}$ & $0.0687^{* *}$ & $0.0927^{* * *}$ & $0.151^{* * *}$ & $0.188^{* * *}$ & $0.230 * * *$ \\
\hline & $(0.0135)$ & $(0.0219)$ & $(0.0163)$ & $(0.0163)$ & $(0.0223)$ & $(0.0418)$ \\
\hline \multicolumn{7}{|l|}{ Modal age empl. } \\
\hline \multirow[t]{2}{*}{$14-19$} & 0.0338 & 0.120 & -0.0628 & -0.146 & 0.202 & 0.198 \\
\hline & $(0.131)$ & $(0.323)$ & $(0.0800)$ & $(0.264)$ & $(0.324)$ & $(0.346)$ \\
\hline \multirow[t]{2}{*}{$20-29$} & -0.0271 & -0.0342 & -0.0246 & $-0.0525^{*}$ & -0.0338 & -0.0367 \\
\hline & $(0.0204)$ & $(0.0290)$ & $(0.0278)$ & $(0.0236)$ & $(0.0331)$ & $(0.0508)$ \\
\hline \multirow[t]{2}{*}{$40-49$} & $0.0373^{* *}$ & $0.0550^{* *}$ & $0.0447^{*}$ & $0.0403^{* * *}$ & 0.0303 & 0.0113 \\
\hline & $(0.0139)$ & $(0.0202)$ & $(0.0174)$ & $(0.0117)$ & $(0.0169)$ & $(0.0273)$ \\
\hline \multirow[t]{2}{*}{$50-59$} & $0.0645^{* * *}$ & $0.0603^{* *}$ & $0.0601^{* *}$ & $0.0645^{* * *}$ & $0.0703^{* *}$ & $0.0728^{*}$ \\
\hline & $(0.0167)$ & $(0.0212)$ & $(0.0221)$ & $(0.0172)$ & $(0.0236)$ & $(0.0361)$ \\
\hline \multirow[t]{2}{*}{$60+$} & 0.0265 & 0.141 & 0.00813 & 0.0662 & 0.0416 & -0.222 \\
\hline & $(0.107)$ & $(0.167)$ & $(0.188)$ & $(0.105)$ & $(0.0923)$ & $(0.123)$ \\
\hline \multirow[t]{2}{*}{ \% empl. tertiary ed. } & $0.00153^{* *}$ & 0.000234 & $0.00148^{*}$ & $0.00193^{* *}$ & $0.00261^{* *}$ & 0.00122 \\
\hline & $(0.000567)$ & $(0.000855)$ & $(0.000639)$ & $(0.000663)$ & $(0.000974)$ & $(0.00102)$ \\
\hline \multirow[t]{2}{*}{ Average tenure empl. } & -0.00196 & 0.000200 & -0.00125 & -0.00248 & $-0.00430^{* *}$ & $-0.00740^{* * *}$ \\
\hline & $(0.00125)$ & $(0.00161)$ & $(0.00112)$ & $(0.00140)$ & $(0.00156)$ & $(0.00192)$ \\
\hline \multirow[t]{2}{*}{$\%$ ISCO $1-2$} & -0.000138 & 0.000143 & -0.000372 & -0.0000300 & -0.000730 & -0.000134 \\
\hline & $(0.000522)$ & $(0.000962)$ & $(0.000553)$ & $(0.000510)$ & $(0.000677)$ & $(0.00116)$ \\
\hline \multirow[t]{2}{*}{$\%$ Perm. contracts } & -0.0000649 & 0.000908 & 0.000705 & 0.000405 & -0.000313 & -0.00115 \\
\hline & $(0.000549)$ & $(0.000667)$ & $(0.000543)$ & $(0.000738)$ & $(0.000531)$ & $(0.00132)$ \\
\hline \multirow[t]{2}{*}{$\%$ Males } & -0.0000653 & 0.000124 & -0.000252 & 0.000306 & 0.000297 & 0.0000279 \\
\hline & $(0.000322)$ & $(0.000487)$ & $(0.000494)$ & $(0.000338)$ & $(0.000412)$ & $(0.000442)$ \\
\hline \multirow[t]{2}{*}{ Constant } & -0.0303 & $-0.761^{* * *}$ & $-0.304^{* *}$ & $-0.208^{*}$ & $0.223^{*}$ & $0.846^{* * *}$ \\
\hline & $(0.0828)$ & $(0.137)$ & $(0.112)$ & $(0.0930)$ & $(0.0974)$ & $(0.165)$ \\
\hline Observations & 7710 & 7710 & & & & \\
\hline Sector fixed effects & Yes & Yes & & & & \\
\hline Country fixed effects & Yes & Yes & & & & \\
\hline
\end{tabular}

Estimates of Eq. (2), with $w^{d 2}$ as the dependent variable.

Regressors also include fitted probabilities (Prob.innov.) from a Probit on innovation status.

Standard errors in parentheses, clustered at the firm level. Significance levels: ${ }^{*} p<0.05,{ }^{* *} p<0.01,{ }^{* * *} p<0.001$ 
reduce wage dispersion at least for those firms located in the middle-top part of the wage dispersion distribution. Concerning the professional wage-gap (in Table 10), we still observe that this measure of within-firm wage inequality does not display statistically significant differences across small innovative and non-innovative firms. It does, however, between small and in medium-large innovators: the latter indeed feature significantly lower professional wage-gaps, especially in the right part of the wage-gap support, that is among relatively more unequal firms.

\section{Conclusions}

In this work we provide an empirical investigation of the relation between innovation and withinfirm wage dispersion, shedding light on a potentially relevant channel to understand wage inequality in major European economies. The general finding is that innovation is indeed a relevant driver of wage inequalities within firms, but the relation shows a good deal of heterogeneity. Indeed, we detect several interesting patterns that vary according to the different measures of wage inequality, and across smaller and larger firms.

Based on the more reliable estimates with propensity score correction, we can summarize our findings as follows. First, if we omit the interplay between innovation and size, innovation has opposite effects on the two measures of wage dispersion. Innovative firms have a larger $90^{\text {th }}$-to- $10^{\text {th }}$ percentile wage ratio than non innovative firms in the bottom and central quantiles of the distribution of this dispersion measure. Conversely, the wage-gap between managerial positions and elementary occupations is smaller in innovative than in non-innovative firms, in this case in the central and upper quantiles. Second, we find evidence of non-trivial interactions occurring between innovation and firm size. Indeed, for small firms, results vary according to the dispersion measure considered: small innovative firms display higher $90^{\text {th }}$-to- $10^{\text {th }}$ percentile wage ratio than small non-innovators in the lower and central quantiles, while we do not observe differences between the two groups in terms of the managers-to-lower-layers wage-gap. Instead, the role of innovation in larger firms is largely independent from the definition of wage dispersion: with both definitions, medium-large innovative firms display lower within-firm inequalities in the central part of the wage dispersion distributions.

The mechanisms behind these findings are not straightforward. We provide here a tentative interpretation in relation with existing theories. On the one hand, according to skill-biased or occupationalbiased explanations of wage inequality, the inequality-enhancing or inequality-reducing effects of innovation that we observe across different wage-dispersion measures and across small vis a vis larger firms should reflect the differential propensity of innovative firms to employ skilled workers and to remunerate apical vs. lower-layers occupations. However, our measures of wage dispersion are adjusted to account for personal characteristics of individual workers and we also control for personal characteristics and composition of the workforce. Thus, skill and occupational biases, alone, cannot entirely explain our findings.

The working of rent-sharing mechanisms are more consistent with our empirical setting, and it can perhaps provide a more compelling explanation, although rent-sharing here has not to be intended in the standard sense hinting at distributional conflicts between the employees and the owners of the firms as in Van Reenen (1996), but rather between different employees. According to this view, the observed positive or negative effects of innovation on wage-gaps reflect the ability and the power of 
different groups of employees (higher- paid vs. lower-paid, managers vs. low-layers occupations) to appropriate the returns from innovation within the firm. Along these lines, if we take models without innovation-size interactions, our findings on the $90^{\text {th }}$-to- $10^{\text {th }}$ percentile wage-gap would suggest that innovation rents mostly go to high-paid workers in firms placed in the bottom and central quantiles of the distribution of this dispersion measure. Instead, low-layers workers seem more able than managers to appropriate innovation rents, at least in firms displaying from median to high levels of inequality, in the central and top part of the support. However, the analysis of innovation-size interactions qualifies this conclusion, essentially indicating that the "inequality enhancing" effect of innovation largely arise within small firms. Indeed, the negative size-innovation interactions that emerge independently from the measure of wage dispersion considered, suggest that both lower-paid employees and lower-layer occupations are more likely to appropriate innovation rents in larger firms than in small firms. One potential explanation for this stronger power of relatively weaker categories of employees in larger firms could be attributed to the usually stronger presence and incidence of unions (and of other forms of employment protection) in medium-large firms. There is indeed empirical evidence that unions and employment protection can compress within-firm inequalities, with relevant implications for the long-standing debate about the effects of labour market reforms seeking to reduce workers' protection and rights. Differently from previous studies, our analysis provide a link between this known result and firm innovativeness. 


\section{References}

Acemoglu, D. (2002): "Technical Change, Inequality, and the Labor Market," Journal of Economic Literature, XL, 7-72.

Acemoglu, D. And D. Autor (2011): "Skills, Tasks and Technologies: Implications for Employment and Earnings," in Handbook of Labour Economics - Vol. 4, ed. by O. Ashenfelter and D. Card, Elsevier.

Autor, D. H., F. Levy, and R. Murnane (2003): "The Skill Content of Recent Technological Change: An empirical exploration," Quarterly journal of economics, 118, 1279-1333.

Baker, G., M. Gibbs, And B. Holmstrom (1994): "The wage policy of a firm," The Quarterly Journal of Economics, 921-955.

Betti, G., B. Cheli, A. Lemmi, And V. Verma (2006): "Multidimensional and longitudinal poverty: an integrated fuzzy approach," in Fuzzy set approach to multidimensional poverty measurement, Springer, 115-137.

Brown, C. And J. Medoff (1989): "The Employer Size-Wage Effect," The Journal of Political Economy, 97, 1027-1059.

Card, D. And S. De La Rica (2006): "Firm-Level Contracting and the Structure of Wages in Spain," Industrial and Labour Relations, 59, 573-592.

Daouli, J., M. Demoussis, N. Giannakopoulos, and I. Laliotis (2013): "Firm-Level Collective Bargaining and Wages in Greece: A Quantile Decomposition Analysis," British Journal of Industrial Relations, 51, 80-103.

Davis, S. J. And J. Haltiwanger (1991): "Wage Dispersion between and within U.S. Manufacturing Plants: 1963-86," Brookings Paper on Economic Activity, Microeconomics, 1991, 115-200.

(1995): "Employer Size and The Wage Structure in U.S. Manufacturing," NBER working papers, National Bureau of Economic Research, Inc.

Dell'Aringa, C. And L. PAgani (2005): "Regional wage differentials and collective bargaining in Italy," Rivista Internazionale di Scienze Sociali, 267-287.

Fournier, J.-M. And I. Koske (2013): "The determinants of earnings inequality," OECD Journal: Economic Studies, 2012, 7-36.

Freeman, C. (1982): The Economics of Industrial Innovation, London: Pinter.

Iranzo, S., F. Schivardi, And E. Tosetti (2008): "Skill Dispersion and Firm Productivity: An Analysis with Employer-Employee Matched Data," Journal of Labor Economics, 26, 247-285.

KAndel, E. AND E. P. LAZEAR (1992): "Peer pressure and partnerships," Journal of political Economy, 801-817. 
Lallemand, T., R. Plasman, and F. Rycx (2004): "Intra-firm wage dispersion and firm performance: Evidence from linked employer-employee data," Kyklos, 57, 533-558.

Lazear, E. P. (1989): "Pay equality and industrial politics," Journal of political economy, 561-580.

LAZEAR, E. P. AND K. L. ShAW (2007): "Wage structure, raises and mobility: International comparisons of the structure of wages within and across firms," Tech. rep., National Bureau of Economic Research.

Martinetti, E. C. (1994): "A new approach to evaluation of well-being and poverty by fuzzy set theory," Giornale degli economisti e annali di economia, 367-388.

Milgrom, P. And J. Roberts (1990): "The Economics of Modern Manufacturing: Technology, Strategy, and Organization," The American Economic Review, 80, 511-528.

Mueller, H. M., P. P. Ouimet, And E. Simintzi (2015): "Wage Inequality and Firm Growth," .

Nickell, S., J. Vainiomaki, And S. Wadhwani (1994): "Wages and product market power," Economica, 457-473.

Nickell, S. AND S. WAdHWAni (1990): "Insider forces and wage determination," The Economic Journal, 496-509.

Skans, O. N., P.-A. Edin, And B. Holmlund (2006): "Wage dispersion between and within plants: Sweden 1985-2000," Tech. rep., Uppsala University, Department of Economics.

Van Reenen, J. (1996): "The Creation and Capture of Rents: Wages and Innovation in a Panel of U.K. Companies," The Quarterly Journal of Economics, 111, 195-226.

Winter-Ebmer, R. AND J. ZweimüLler (1999): "Intra-firm wage dispersion and firm performance," Kyklos, 52, 555-572.

Zoghi, C. (2011): "The Distribution of Skills and Wages within Firms," Working paper, US Bureau of Labor Statistics.

Zoghi, C. And R. Mohr (2012): "Within-Firm Wage Compression and Job Skills in the National Compensation Survey," Tech. rep., US Bureau of Labor Statistics. 


\section{Appendix}

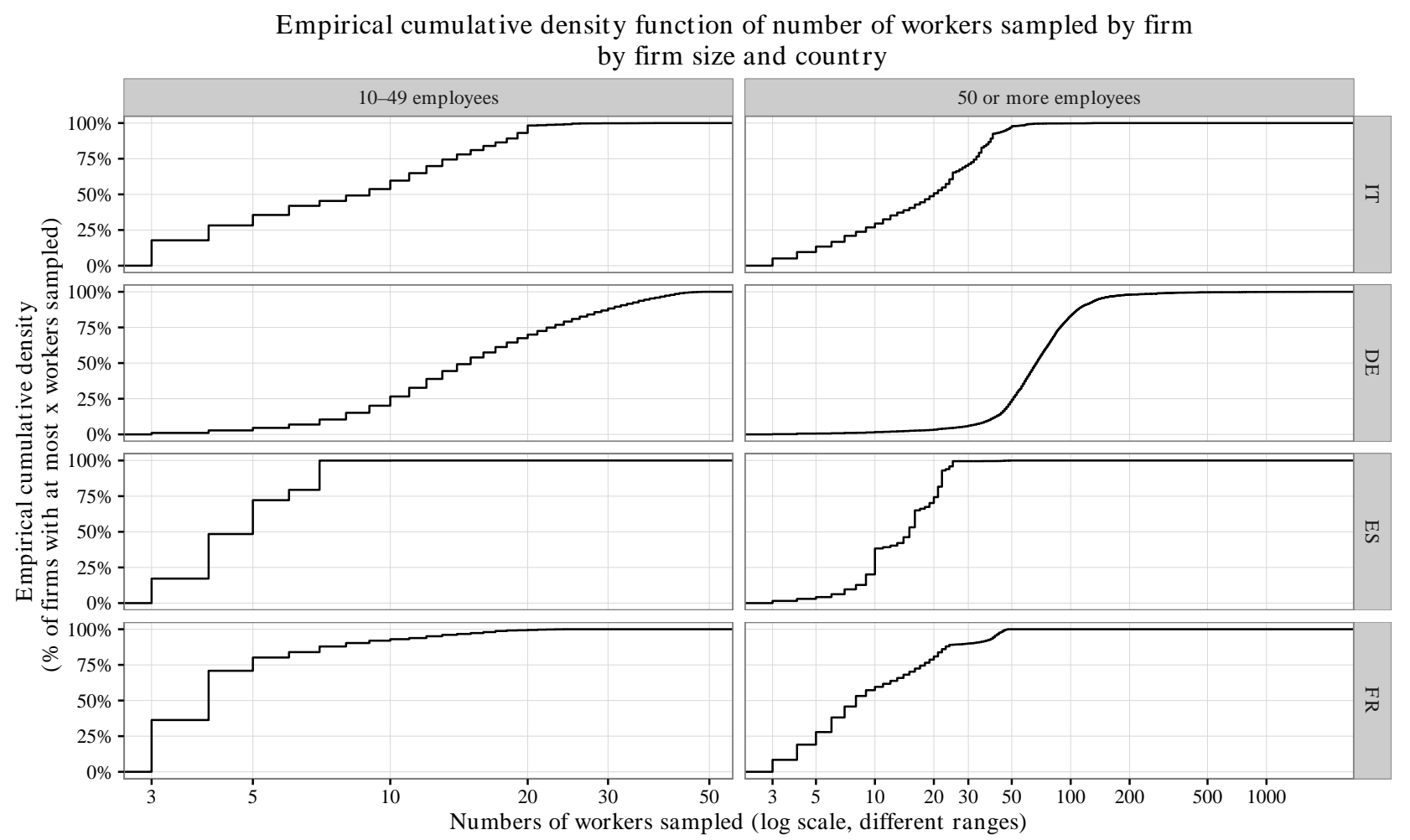

Figure 1: Distribution of number of sampled employee observations in relation to firm size by country. 


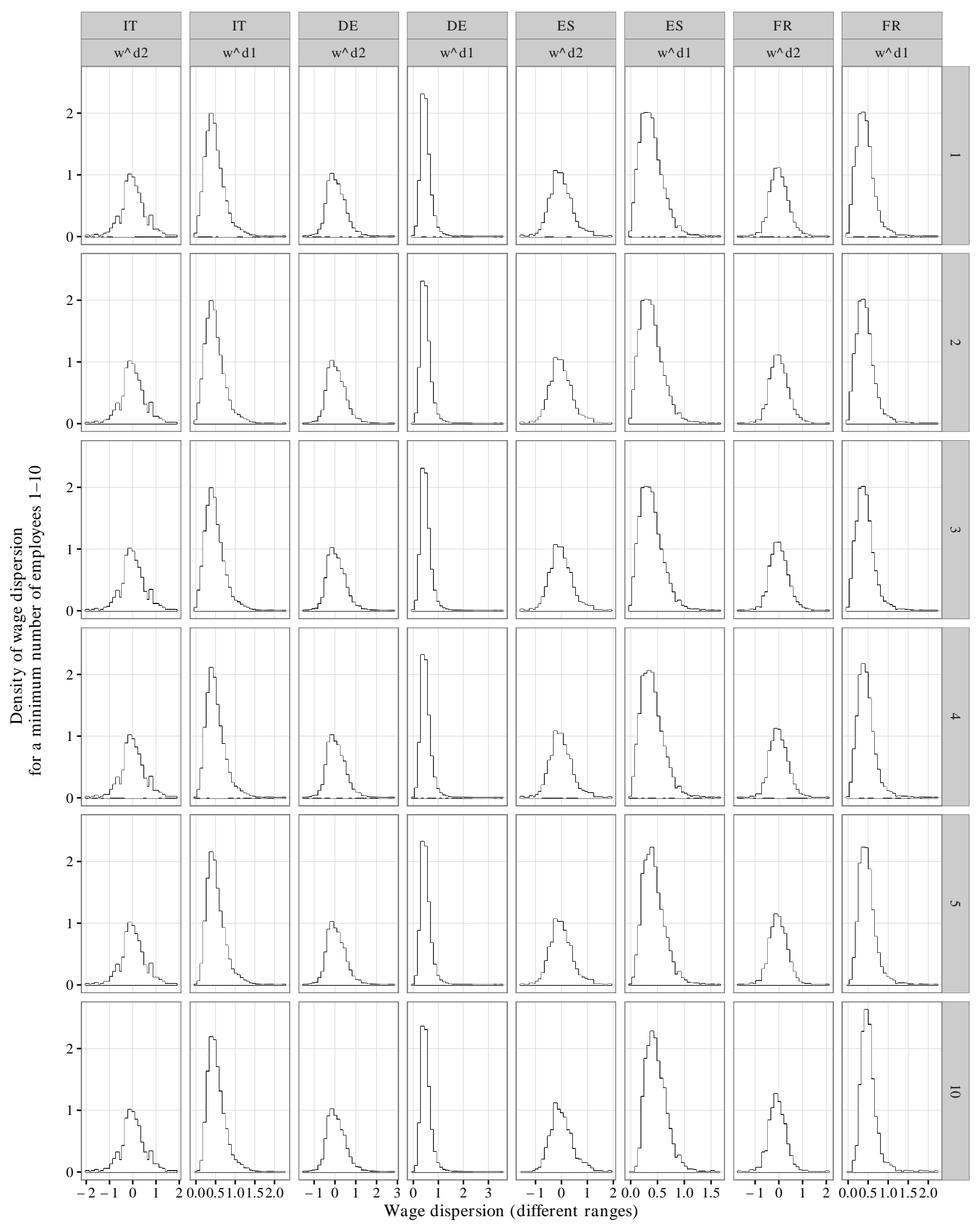

Figure 2: Distribution of wage dispersion across countries with different minimum number of employees sampled. 